Historic, Archive Document

Do not assume content reflects current scientific knowledge, policies, or practices. 


\section{PEONIES, IRIS, \\ PHLOX and other \\ PERENNIALS}

OFFERED BY THE

Cherry Hill Nurseries

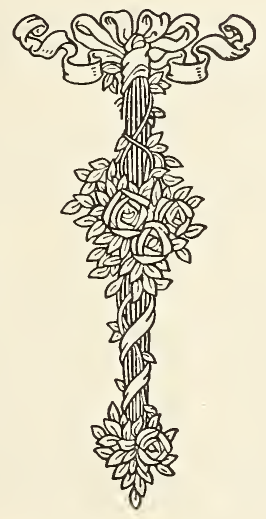

$1920 \cdot 1921$

T. C. THURLOW'S SONS, INC. WEST NEWBURY, MASS. 


\section{LIST OF AWARDS}

The following awards will in a measure testify to the quality of our stock, but to appreciate more fully their value one must visit us in mid-June, when our peony flowering season is at its height.

1893 Appleton Silver Medal, Collection of Peonies, Boston, Mass.

1897 Kelway Bronze Medal, Collection of Peonies, Boston, Mass.

1899 Kelway Bronze Medal, Collection of Peonies, Boston; Mass.

1903 Kelway Silver Medal, Collection of Peonies, Boston, Mass.

1909 M. H. Society Silver Medal, Collection of Peonies, Boston, Mass.

1914 M. H. Society Gold Medal, Popularizing Peonies; Boston, Mass.

1915 A. P. Society Gold Medal, Best Collection of Peonies, Boston, Mass.

1915 M. H. Society Silver Medal, Seedling Cherry Hill, Boston, Mass.

1915 Pan-American Silver Medal, Peonies, San Francisco.

1916 N. B. H. Society Silver Medal, Collection Peonies, New Bedford, Mass.

1917 M. H. Society Silver Medal, Best Collection Peonies, Boston, Mass.

1917 A. P. Society Silver Medal, Best Collection Peonies, Boston, Mass.

1918 A. P. Society Silver Medal, Best Collection Peonies, Boston, Mass.

1918 N. B. H. Society Silver Cup, Collection Peonies, New Bedford, Mass.

1918 M. H. Society Silver Medal, Best Collection Peonies, Boston, Mass.

1919 M. H. Society Silver Medal, Best Collection Peonies, Boston, Mass.

1919 M. H. Society Silver Medal, Collection Peonies, Boston, Mass.

1919 A. P. Society Gold Medal, Best Collection Peonies, Detroit, Mich.

Besides hundreds of first and second prizes in keen competition on individual peonies exhibited at the leading horticultural exhibits in New England.
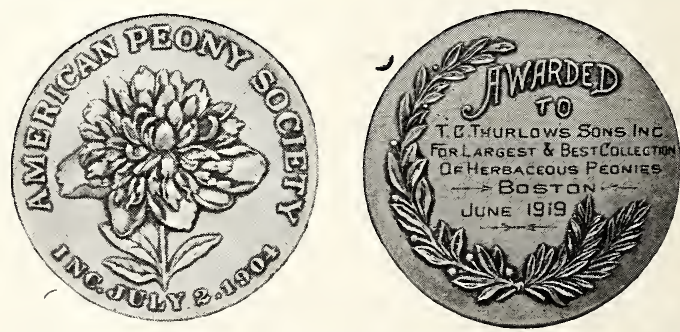

GOLD MEDAL awarded us by American Peony Society in 1919, at Detroit, Mich. 


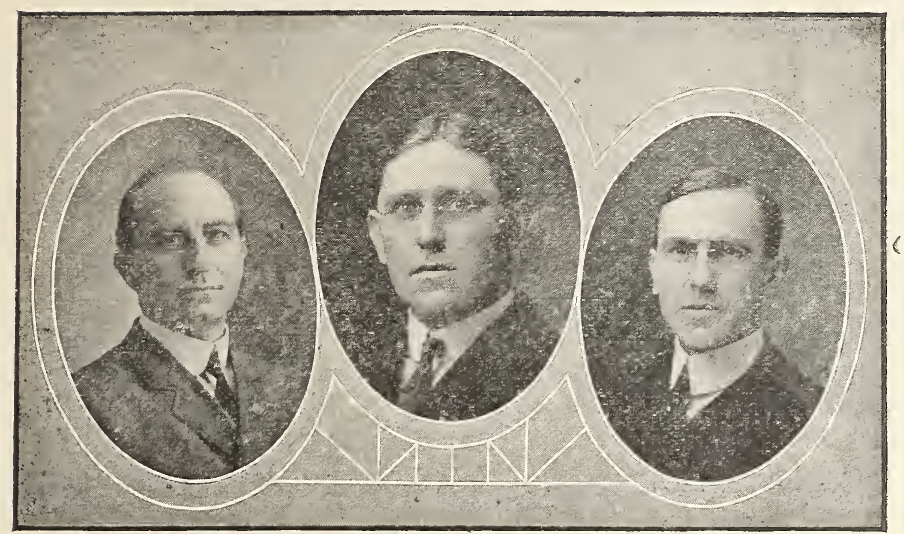

G. C. THURLOW, President

D. C. STRANGER, Vice-President

W. H. THURLOW, Treasurer

\section{FOREWORD}

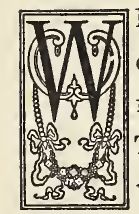

INTER, with its grip of ice and snow, dark dreary days and chilling winds, has once more taken flight, and a glorious springtime now is ours. The songs of the birds, the budding shrubs and trees, earth's new carpet of green, and the warm sunshine about us, all give token that a bountiful summer is at hand.

At this time our thoughts are turning more and more to the great outdoors, where Mother Nature is calling us with a voice and spirit that will not be denied.

It is our privilege to help in the great constructire work that is to make our Nation the most beautiful Nation on earth, and we can direct our efforts in no better way than in making our gardens a vision of delight, a place where truly there is sweet rest for both body and soul.

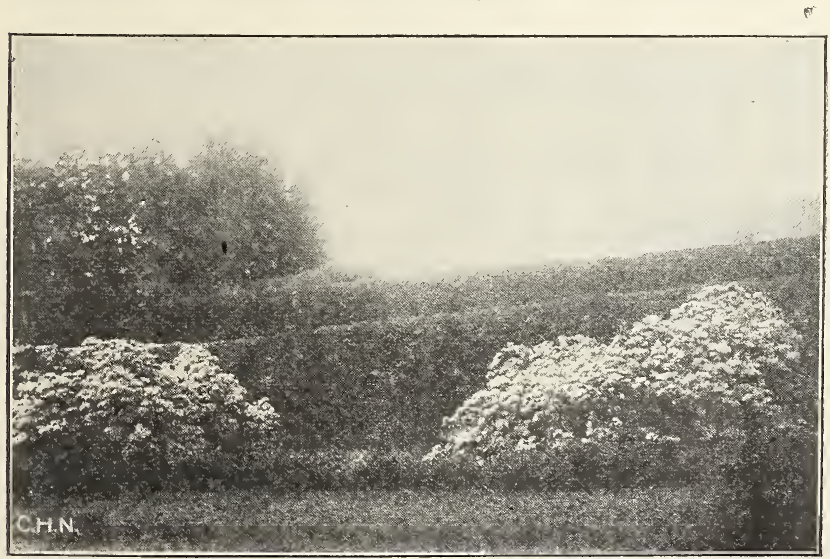

A VISTA AT CHERRY HILL NURSERIES 


\section{SHIPPING NOTES}

All of the peonies listed in this catalog are thrifty and vigorous plants that will be dug as ordered and packed in a satisfactory manner, so as to reach their destination in the best of shape.

Small lots may be sent by parcel post, but larger lots we would recommend by express.

Be' sure to state when ordering about when you wish your stock shipped, whether post or express, and your exact shipping point.

It may happen occasionally that our stock of a certain variety has been exhausted, and we will then substitute a similar color of a higher grade at the same price unless otherwise requested.

\section{PEONY NOTES}

The growing of choice peonies at Cherry Hill began nearly fifty years ago, when Thomas C. Thurlow started to get together what he hoped would become one of the choicest collections to be found in this country.

From the very start his efforts met with success and in a few years he was classed as one of the foremost peony growers in America, and his opinions and judgments were much sought after and prized by those engaged in growing this "Queen of Flowers."

In the late nineties, owing to ill health, he decided to sell the bulk of his collection, and the largest sale of peonies on record was made to the Chicago Carnation Co. in 1899, Mr. Thurlow reserving only two of each of his choicest varieties. His passion for flowers, however, could not long remain quiet, and he soon began to purchase new and rarer varieties from the leading European and American growers.

In this painstaking way the present collection of peonies at Cherry Hill began its growth, and from time to time the present partners have spared neither pains nor expense to add such varieties of merit as would enhance its value.

In the fall of 1914 the Gold Medal Collection of E. J. Shaylor was bought, and since then two other choice collections have been added. These purchases, coupled with those from other peony growers of note, both in this country and abroad, have provided us with what we unquestionably believe is the largest number of real choice peonies to be found in any single planting in the entire world.

From over three hundred thousand seedlings raised by us in the last twenty-five years we have selected in the vicinity of fifty new varieties of the highest merit, which we will introduce to our friends from time to time as our stock warrants. 


\section{PEONY CULTURE}

One may transplant peonies almost any time from the first of April until the ground freezes in the fall. The best time, however, is after the first of September, although one may secure quite good results if the roots are set out in the spring before the buds have sprouted.

As we store no peonies through the winter, but dig them when ordered, we recommend that when wanted for spring planting they should be ordered early, so they may be dug before the buds have started and then brought into our cool storage cellar, where they can be kept dormant for a week or ten days.

Peonies do best when planted in a light rich soil, but in no case should manure or fertilizer be placed so it will come in direct contact with the roots. If the soil is poor where the peonies are to be planted, it is recommended that the hole be dug and fresh rich earth be put in in place of that taken out.

Peonies respond very readily to a manure or fertilizer put on top of the ground in the spring, just as soon as the snow is off, and then forked in gently as soon as the ground can be worked.

Many times small plants will not show their best form, size or color the first year set out but will continue to improve each year and do best when left undisturbed for eight or ten years. Those who wish quick results, however, will do well to set out older plants either in the two or three year size.

Peonies as a rule are very free from pests or diseases. Occasionally, however, in especially wet seasons, a stem will be found rotting, and in all such cases it is best to cut the stem below the ground to the top of the tuber, thus preventing the fungus from spreading.

Liberal watering of the ground around the stems of the plants will produce wonderful results both in the size and color of blossom.

\section{SINGLE HERBACEOUS PEONIES SERIES A}

50 cents each; $\$ 5.00$ per dozen, except as noted

For 2 year clumps add $50 \%$ to price.

For 3 year clumps add $100 \%$ to price.

For 4 year clumps add $150 \%$ to price.

In listing this series we begin with the varieties which are the first to bloom with us. By a careful selection, beginning with these, then followed by the Chinese single varieties, and later, by the double varieties, one may have a peony-flowering season of from six to eight weeks.

The single varieties are not nearly as good for cut flowers as are the double ones, but for the garden or landscape effect they are especially adapted, as their large, wavy, silk-like blossoms, with their bright golden stamens, give a gracefulness that is very pleasing. 
At evening the blossoms gradually close until they resemble large beautiful rosebuds of exquisite tints and shades.

When requested we will gladly suggest varieties that will give a continuation of bloom throughout the peonyflowering season.

AREOS, beautiful soft silky pink fading to pure white. Early. ARGUS, deep satiny rose, very attractive.

CELESTE BROCHET (Brochet), large handsome milk-white flowers minutely flecked with lilac, giving a total effect of soft flesh pink. Stock limited. $\$ 2.50$ each.

CLAIRETTE (Dessert), very large white silky flowers with light pink shadings at the base of the petals. One of the most beautiful. Free bloomer in clusters. $\$ 2.50$ each.

DEFIANCE, very brilliant crimson with bright golden stamens making a very striking appearance. 75 cents each.

DREADNOUGHT (Barr), deep crimson, considered exceptionally fine. 75 cents each.

EMILY, soft satiny-rose pink, very beautiful.

HERMES, a very delicate shade of hydrangea pink.

LADY LILLIAN OGLE (Kelway), large, handsome, silky blushwhite blossoms. $\$ 1.50$ each.

LA FIANCEE (Dessert 1902), large white flowers with beautiful golden centre. Plant tall and vigorous. $\$ 2.00$ each.

MILLAIS, deep, dark-red, with pronounced bright yellow stamens.

MRS. KEY, bright, vigorous satiny crimson. Very choice and desirable. 75 cents each.

PRINCE ALEXANDER, rich cherry color. Very fine.

PRINCE BISMARCK, deep rich crimson.

PRINCESS OF WALES (Barr), a beautiful wild-rose pink. I.imited stock for sale. $\$ 2.00$ each.

PURITY (Kelway), a fine pure white of extra large size. Estra choice. $\$ 2.00$ each.

ROSY DAWN (Barr), a plant of somewhat spreading habit, bearing beautiful flowers having a flesh-pink tint when opening. but changing to pure white later on. Stock limited. $\$ 2.00$ each.

SINGLE WHITE, choice seedlings of our own raising. Glistening white flowers of good size with bright golden stamens. $\$ 1.00$ each.

STANLEY, a free-blooming variety with deep crimson blossoms having a beautiful golden centre. 75 cents each.

THE QUEEN (Kelway), a handsome blush-white flower of large size and borne profusely on strong growing stems. $\$ 1.50$ each.

WHITLEY MAJOR, a vigorous grower with extra large blushwhite blossoms fading to pure white. Centre a mass of golden stamens. $\$ 1.50$ each.

\section{RARE SINGLE JAPANESE PEONIES}

The blooming period of these choice and interesting varieties is somewhat later than that of the Chinese varieties. As they propagate slowly the number offered for sale is of necessity very limited.

DOG ROSE (Kelway), a very beautiful flower, bearing a close resemblance to the wild rose. Petals are soft and silkv, centre deep golden. $\$ 3.00$ each.

ISANI GIDUI, an exceptionally nice glistening white of good size with large bright yellow centre. $\$ 10.00$ each. 
KING OF ENGLAND, a deep rich red with bright golden stamens having a lining of bright red as flower develops. Not for sale.

PERLE BLANCHE (Dessert), an exquisitely shaped cup flower of glistening white with a golden centre. Not for sale.

TAMATBAKO, a beautiful bloom of soft pink, very clear and bright, with large centre of deep yellow stamens. $\$ 8.00$ ea.ch.

WHITE LADY, this plant is somewhat dwarf and is considered one of the very finest of the Japanese varieties. Flowers are quite large and of a pure white with large full centre of bright golden stamens. Scarce. $\$ 10.00$ each.

YESO, narrow centre petals a silvery white tinged with straw and minutely tipped with carmine. Very choice. $\$ 8.00$ each.

\section{LEMOINE'S HYBRIDS}

These hybrids (Chinese Peony X Peony Wittmanniana) have a beauty peculiar to themselves and flower quite a little earlier than the Chinese singles.

AVANT-GARDE, a medium sized flower of a beautiful pale pink with deeper golden veinings. Centre a mass of golden stamens. $\$ 2.50$ each. Sold until 1921.

LE PRINTEMPS, flowers quite large and of a creamy yellow shade with faint reddish veinings across centre. Exceptionally choice. $\$ 2.50$ each.

MAIFLEURI, beautiful delicate flesh-white with a tinge of rich creaminess, quite large and very attractive. $\$ 2.50$ each.

PAEONIA LUTAEA, plant somewhat dwarf and bushy, with deep-cut foliage, flowers about three inches across and of a rich buttercup yellow with a deeper centre. Blooms quite late. Tery odd and pleasing. $\$ 2.00$ each. Sold out until 1921.

\section{EUROPEAN PEONIES}

50 cents each; $\$ 5.00$ per dozen except as noted

The following varieties are among the earliest bloomers, usually beginning about mid-May and continuing until the first or second week in June, thus extending the peony-blooming season about two weeks.

OFFICINALIS ALBA PLENA. This is the true white and not to be classed with the Mutabilis. Beautiful double white blossoms delicately tinted with pink at the base when blossom first opens. $\$ 1.50$ each. Sold out.

OFFICINALIS ROSEA PLENA, beautiful rose-pink blossoms of good size and substance. Valuable for Memorial Day decoration.

OFFICINALIS RUBRA PLENA, rich deep red flowers of medium to large size. The old-fashioned peony of our grandmother's day but of far sweeter odor. Comes into bloom about Memorial Day.

OFFICINALIS SABINA, a rich crimson single with centre very attractive with its deep golden stamens.

PETER BARR (Barr), single flowers two or three inches across, very dark crimson. Plant somewhat dwarf. Finely cut foliage. Usually blooms about mid-May. Very attractive. $\$ 2.00$ each. Sold out.

SMOUTHA, this peony follows Peter Barr in season. Very finely cut foliage. Flowers a bright beautiful silky crimson. Total effect very pleasing. $\$ 2.00$ each. 


\section{DOUBLE HERBACEOUS PEONIES}

\section{SERIES B}

\section{5 cents each; $\$ 3.50$ per dozen.}

Two year clumps 53 cents each, $\$ 5.25$ per dozen.

Three year clumps 70 cents each, $\$ 7.00$ per dozen.

Four year clumps 88 cents each, $\$ 8.75$ per dozen.

These varieties have all been tested out in our trial grounds and have proved their worth. Other series will list the more valuable ones.

CANDIDISSIMA (Calot 1856), a very pleasing well formed blossom of medium size. Guard petals a pure white blending to a light sulphur yellow in the centre.

COMTE DE DIESBACH (Calot 1873), this variety follows the Officinalis Rosea and Rubra in blooming. Flowers are of a variegated light crimson, medium to large size and lasting.

HENRI DEMAY (Calot 1866), flowers rich crimson and of good size, foliage broad and deep green.

LOUIS VAN HOUTTE (Calot 1867), brilliant crimson flowers of medium size and good form.

PSYCHE, blossoms of a deep rose at guard petals with centre quite a little lighter. Useful for landscape work. Sold out. QUEEN VICTORIA, blossoms a rich creamy white, guard petals broad, centre quite full with sometimes a splash of red on central petal. Very good.

\section{SERIES C}

\section{0 cents each; $\$ 5.00$ per dozen.}

Two year clumps 75 cents each, $\$ 7.50$ per dozen. Three year clumps, $\$ 1.00$ each, $\$ 10.00$ per dozen. Four year clumps $\$ 1.25$ each, $\$ 12.50$ per dozen.

Many fine varieties are in this collection and, although of older origin, are well worth a place in one's garden.

ACHILLE (Calot 1865), blossoms of a bright, clear, flesh color, quite large and well formed.

ALEXANDRE DUMAS (Guerin 1862), large, free blooming and well-formed flowers of a soft satiny rose color. Mid-season.

ALICE DE JULVECOURT (Pele 1857), medium to large blossoms with creamy white collar, petals slightly splashed with crimson.

DELICATISSIMA, a free bloomer of delicate soft pink flowers fading to almost white. Early.

DR. BRETONNEAU (Verdier 1854), (syn. Lady Bramwell), large well-formed flowers of clear pink. Very choice. Early to mid-season.
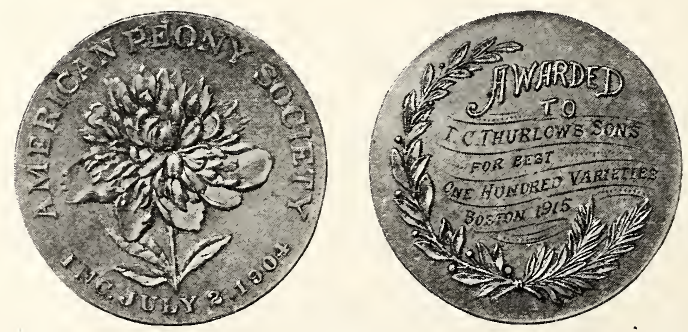

GOLD MEDAL Awarded 1915 by the American Peony Society 
DUC DE WELLINGTON (Calot 1859), large well-formed flowers of satiny white. Midseason to late.

EDOUARD ANDRE (Mechin 1874), medium size blossoms of a satiny crimson maroon with rich golden centre. Midseason.

EDULIS SUPERBA (Lemon 1824), deep rosy pink blossoms striped with carmine. Blooms about same time as Comte de Diesbach.

FESTIVA MAXIMA (Miellez 1851), one of the most popular peonies in existence. Extra large ivory-white blossoms occasionally flecked with crimson. Well formed and excellent as a cut flower.

GOLDEN HARVEST (Rosenfield 1900), a striking variety with rose guard petals and creamy yellow tufted centre interspersed with pink. Mid-season.

JOHN FRASER, one of the early double peonies with bombshape blossoms of deep rose-pink with a silvery reflex.

MADAME COSTE (Calot 1873), a nother early blooming, double peony with flesh-pink guard petals and white tufted centre tinged with cream.

MADAME FOREL (Crousse 1881), a large flower of good substance with deep rose centre and petals silver tipped. Attractive.

MARECHAL VAILLANT (Calot 1864), extra large, deep crimson blooms of good form and substance and so heavy that stems need supporting. Very late.

NOBLISSIMA (Miellez 1858), quite a tall variety with reddishrose blossoms of medium size. Excellent for landscape work. Midseason to late.

PHILOMELE (Kelway), a very pretty flower of medium size. Guard petals light rose, petaloids yellow with rose tuft in centre. Midseason to late.

TORQUEMADA, a large well-formed and lasting flower of clear light pink. Midseason.

\section{SERIES D}

\section{5 cents each; $\$ 7.50$ per dozen.}

Two year clumps $\$ 1.13$ each, $\$ 11.25$ per dozen.

Three year clumps $\$ 1.50$ each, $\$ 15.00$ per dozen.

Four year clumps $\$ 1.88$ each, $\$ 18.75$ per dozen.

ADELAIDE DELACHE, a profuse bloomer of deep rose blossoms with creamy white tips. Midseason.

AUGUSTIN d'HOUR (Calot 1867), (syn. Marechal MacMahon), quite a free bloomer of large full rich carmine flowers. Midseason.

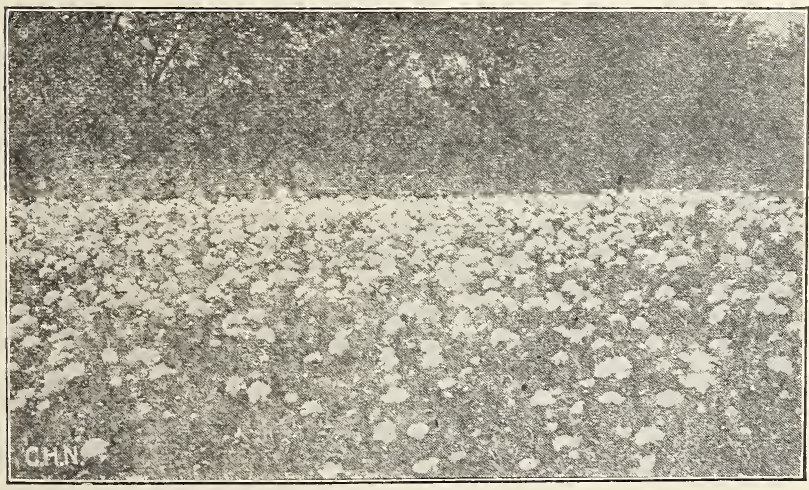


DELIA, an extra nice ivory-white, with sulphur-yellow centre of semi-bomb type. Midseason.

DISTINCTION (Dessert 1895), quite an attractive blossom of good size with lively red guard petals, centre petals striped with creamy yellow. Midseason.

DOCTEUR CAILLOT (Verdier 1856), large semi-rose shaped blooms of a tyrian rose color and good form. A free bloomer. Midseason.

DUCHESSE DE NEMOURS (Calot 1856), a beautiful white cupshaped blossom with a light sulphur-yellow centre. Early midseason.

GENERAL CUSTER (Terry), a medium-sized semi-double bloom of bright pink with lighter centre showing two rows of stamens.

GRACE D. BRYAN (Rosenfield 1908), a tall-growing variety, flowers a brilliant light pink, extra large and very double. Late.

JEANNE d'ARC (Calot 1858), an extra nice bloom of good size and form, color soft rose with creamy white centre tinted carmine. Midseason.

LA COQUETTE (Guerin 1861), large deep rose-pink flowers with centre somewhat lighter and carmine flecked. Midseason.

LA TULIPE (Calot 1872), large tulip-shaped buds of bright pink striped with crimson. Blossom opens a clear flesh pink. Extra nice. Midseason.

MME. BARILLET DESCHAMPS (Calot 1868), a variety well adapted for landscape work, blossoms large, well formed and of a beautiful soft rose with silvery reflex. Foliage quite broad. Midseason.

MME. CAMILLE BANCEL (Crousse 1897), blooms light pink with silvery reflex, large and of good form. Excellent as a cut flower. Late.

MME. de GALHAU (Crousse 1883), a distinct globular-shaped blossom of a delicate pink with lighter guard petals. Late.

MME. de GOVIN (Crousse 1875), a choice variety, blooms clear shell-pink with centre somewhat lighter and crimson flecked. Late.

MME. de VERNEVILLE (Crousse 1885), a beautiful milk-white peony with centre flesh-pink when first opened. Centre petals sometimes tipped with carmine. Early to midseason.

MME. DUCEL (Mechin 1880), extra large globular blooms of a beautiful rose-pink with silver reflex resembling a mammoth chrysanthemum. Very fine. Midseason.

MME. MECHIN (Mechin 1880), one of the best of the dark reds, a dark glossy garnet showing its light golden stamens in pleasing contrast. Very nice. Midseason.

MODELE de PERFECTION (Crousse 1875), large full flowers of a light rose-pink with silvery shadings, centre somewhat darker. Late.

M. BOUCHARLAT AINE (Calot 1868), strong plants bearing immense imbricated blooms of soft pink. Very good for landscape work.

PRINCE OF WALES (Kelway), a semi-double dark crimson of medium size with a pronounced showing of golden stamens. Midseason.

SOUVENIR de I'EXPOSITION du MANS (Mechin 1880), a pretty blossom of deep red having a silvery reflex. Midseason.

SOUVENIR de I'EXPOSITION UNIVERSELLE (Calot 1867), a lively silky light pink of attractive appearance. Choice as a cut flower. Midseason.

TRIOMPHE de PARIS (Guerin 1850), a large flower of deep rose with the centre petals a creamy buff.

UMBELLATA ROSEA (Guerin 1895), medium to large blossoms with guard petals a violet-rose and centre petals a rreamy white. Formerly listed as Sarah Bernhardt. Early. 
VISCOUNTESS FOLKESTONE, a distinct white with a row of narrow petals interspersing between the guard petals and the centre. Midseason.

ZOE CALOT (Miellez 1855), a large flower of semi-flat type with a soft pink coloring.

\section{SERIES E}

\section{$\$ 1.00$ each ; \$10.00 per dozen.}

Two year clumps $\$ 1.50$ each, $\$ 15.00$ per dozen. Three year clumps $\$ 2.00$ each, $\$ 20.00$ per dozen. Four year clumps $\$ 2.50$ each, $\$ 25.00$ per dozen.

This series embraces what we consider the choicest of the medium priced peonies. All have been proved in our trial grounds and have our unqualified endorsement.

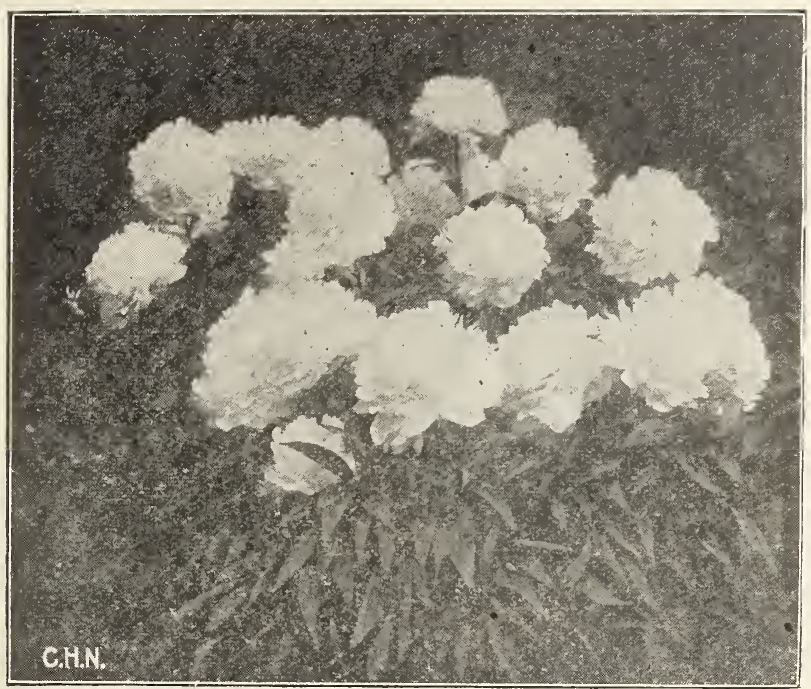

A FIVE YEAR PLANT IN OUR GARDENS

ARMAND ROUSSEAU (Dessert \& Mechin 1893), strong plants bearing large and elegant blooms of a bright rose-pink with golden stamens intermixed with the central petals.

AVALANCHE (Crousse 1886), one of the most popular peonies in existence. Very large ivory-white blossoms with a very full centre many times splashed with carmine. Excellent as a cut flower. Midseason.

BOULE de NEIGE (Calot 1862), very large cup-shaped blooms of a clear snowwhite with a creamy-white centre. Centre petals sometimes have an accidental edging of carmine. Early midseason.

CAROLINE ALLAIN (Kelway), an exceptionally fine white of marked quality with narow central petals. Midseason.

COURONNE d'OR (Calot 1872), an extra large pure white flower with very full centre showing golden stamens. Very fine form and valuable as a cut flower. Midseaosn to late.

DORCHESTER (Richardson), plant somewhat dwarf, bloom of a delicate pink of good size and fine form. Late.

EDITH LYTTLETON (Kelway), quite an early and free blooming variety of large globular form. Coloring a beautiful deep shell-pink with light satiny tips. 
EUGENIE VERDIER (Calot 1864), (syn. Pottsii Alba), a tall and free blooming variety of good size and form. Delicate flesh centre with lighter outer petals of a beautiful satiny sheen. Midseason.

FELIX CROUSSE (Crousse 1881), a compact globular bloom of large size and fine form. Deep ruby red, centre shading somewhat deeper. Very choice. Midseason to late.

GLOIRE de CHARLES GOMBAULT (Gombault 1886), a very interesting variety. Guard petals a light satiny rose with a very full centre of creamy white having a rose tuft in the centre. Sold out.

GLOIRE de CHENONCEAUX (Mechln 1880), large medium rosepink flowers, with centre petals streaked with red. Midseason.

GRANDIFLORA (Richardson), very large silvery pink flowers of semi-fiat type. One of the best. Late.

HELENA, a delicately formed white peony with a faint straw centre. Very pretty. Midseason.

JULES CALOT (Calot 1861), large double flowers of a beautiful shade of deep rose-pink. Blooms very freely and is choice as a cut flower. Late.

LAMARTINE (Calot 1860), enormous flowers of a pleasing delicate pink shade. Very popular both for landscape and as a cut flower. Midseason.

L'INDISPENSABLE, very large full blooms of a clear shell-pink. Excellent as a cut flower.

MME. CALOT (Mieliez 1856), large, flesh-pink blossoms, very attractive as a cut flower. Midseason.

MME. CROUSSE (Calot 1866), a very large and beautiful pure white flower sometimes showing a crimson fleck on a central petal. Extra. Midseason.

MLLE. DESBUISSONS (Crousse 1893), large imbricated flowers of a pleasing satiny pink. Valuable for landscape effect. Midseason.

MME. EMILE GALLE (Crousse 1881), one of the most attractive and valuable of the medium priced pink peonies. Medium size and clear shell-pink with silvery pink edging. Midseason to late.

MME. GEISSLER (Crousse 1880), very large semi-flat blossoms of a delightful rose-pink with silvery tippings. Extra choice as a cut flower.

MLLE. LEONIE CALOT (Calot 1861), (syn. M. Charles Leveque), a very soft salmon-pink changing to a flesh-white and blooming freely in clusters. Good size. Late.

MME. LOIS MERE (Calot 1863), large full flowers of a delicate flesh-pink, petals edged with crimson. Late.

MLLE. MARIE CALOT (Calot 1872), a pure milk-white flower of good size and form with occasional edgings of crimson. Late midseason.

MARIE (Calot 1868), well formed white blossoms with a faint tinge of light canary yellow. Flowers well formed and lasting. Late.

MARIE JACQUIN (Verdier), (syn. Bridesmaid), exquisitely formed flowers, opening a delicate flesh-white and changing to a pure white as the blossom gets older. When partly opened they resemble beautiful water lilies. Strong growing and free blooming. Midseason.

MARIE LEMOINE (Calot 1869), plants somewhat dwarf, bearing large full creamy white flowers with golden reflex. Very late.

MIREILLE (Crousse 1894), flowers quite large and of a beautiful milky-white color. Late.

MR. MANNING (Kelway), a very choice deep satiny crimson, showing a row of bright golden stamens. Late.

MODESTE GUERIN (Guerin 1845), large globular blossoms of a bright solferino pink, very vigorous and extra good as a cut fiower. Midseason. 
MONSIEUR DUPONT (Calot 1872), a well-formed ivory-white with central petals streaked with carmine. Very popular as a cut flower. Late.

OCTAVIE DEMAY (Calot 1867), large flowers of pink and white beautifully blended and fragrant. Plant somewhat dwarf. Midseason.

PIERRE DESSERT (Dessert \& Mechin 1890), large full flowers of a dark satiny garnet. Very fine. Midseason.

PRINCESS IRENE (Kelway), one of the best of the so-called yellows, guard petals a clear flesh color with centre petals a light sulphur yellow. Midseason.

RUBRA SUPERBA (Richardson), a choice dark crimson of fine form and substance. Very late.

SOUVENIR de I'EXPOSITION de BORDEAUX (Dessert 1896), extra good as a landscape variety with its large clear blooms of vinuous red. Midseason.

TRIOMPHE de I'EXPOSITION de LILLE (Calot 1865), one of the very best pinks, extra large cup-shaped blooms of a beautiful hydrangea shade having petals somewhat deeper splashed. Midseason.

VENUS (Kelway), a very beautiful compact bloom of a delicate shell pink. Extra good as a cut flower and called by experts "one of the best." Midseason.

VIRGINIE (Calot 1858), large fragrant blooms of shell pink fading to a flesh color. Bright golden stamens showing in centre of fully opened flower. Extra nice. Midseason to late.
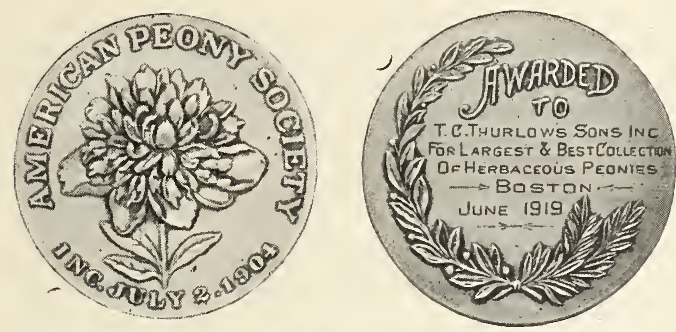

SILVER MEDAL awarded us by American Peony Society in 1919

\section{SERIES F}

\section{$\$ 1.50$ each; $\$ 15.00$ per dozen.}

Two year clumps \$2.25 each, \$22.50 per dozen. Three year clumps $\$ 3.00$ each, $\$ 30.00$ per dozen. Four year clumps $\$ 3.75$ each, $\$ 37.50$ per dozen.

ALBERT CROUSSE (Crousse 1893), extra large blooms of a beautiful light salmon-pink. Extra good as a cut flower. Late.

ALFRED de MUSSET (Crousse 1885), large double blooms of a light silvery pink with outside petals shading to a delightful flesh pink. Late.

ASA GRAY (Crousse 1886), beautiful large flesh-pink flowers with minute carmine dots. Very choice and valuable. Midseason.

AURORE (Dessert 1904), a loosely-formed cup-shaped variety, milky white with golden stamens showing among the petals, making it a very desirable variety.

BARONESS SCHROEDER (Kelway), one of the most popular peonies in existence. Flowers of good size and substance, flesh-pink changing to a beautiful milk-white. Plant a strong grower. Midseason.

CLAIRE DUBOIS (Crousse 1886), very large globular-shaped blooms of satiny-pink tipped with silver. Vigorous and a free bloomer. Iate. 
COQUELIN (Dessert), an early variety of good size. Color a delightful china pink with silvery reflex, blossom cupshaped.

EUGENE VERDIER (Calot 1864), a beautiful hydrangea-pink variety, with outer edges tinted lighter, of good form and substance. Late.

JAMES KELWAY (Kelway), a free blooming flower of magnificent size and quality, opening a delicate flesh-pink and changing to a most beautiful white with bright golden stamens showing in centre. Midseason.

LA ROSIERE (Crousse 1888), a very charming variety with the exquisiteness of a tea rose. Light sulphur-yellow guard petals with deeper centre. Medium size and good substance. Midseason.

LA TENDRESSE (Crousse 1896), a delightful milk-white variety with an occasional splashing of carmine, blossoms of good size and borne freely in clusters. Midseason.

MME. EMILE LEMOINE (Lemoine 1899), an extra nice variety, soft flesh-white in color and of large size. A good bloomer and fine as a cut flower. Midseason.

MLLE. ROUSSEAU (Crousse 1886), a valuable large milk-white peony with carmine dots splashed in centre and on back. Flowers of good substance and lasting.

MARCHIONESS OF LANSDOWNE (Kelway), large double flowers of an exquisite shade of hydrangea-pink, sometimes flecked with carmine. Midseason.

MARGUERITE GERARD (Crousse 1892), large full blossoms of flesh-pink fading to a creamy white, showing a row of golden anthers. A strong grower and free bloomer. Late.

M. JULES ELIE (Crousse 1888), an extra large bright pink, resembling a huge chrysanthemum. Excellent in every way. Midseason.

NORFOLK (RIchardson), a beautiful soft pink flower of large size. Cup-shaped. Late.

PERFECTION (Richardson), another peony deserving a place in one's garden. Large blossoms of light pink changing to a flesh-white. Late.

PETITE RENEE (Dessert 1899), large semi-double flowers of a deep rose-pink with darker shadings, central petals striped with creamy white. Resembles a giant orchid. Midseason.

SIMONNE CHEVALIER (Dessert 1902), very large and beautiful, soft salmon-pink with lighter tintings. Early to midseason.

SOUVENIR dU DR. BRETONNEAU (Dessert 1896), a large, somewhat loosely-formed flower of a deep rose-pink, free flowering. Midseason.

SUZANNE DESSERT (Dessert \& Mechin 1890), a free-blooming variety of good size and form. Guard petals a deep pink with centre of a lighter shade with silvery reflex. Midseason.
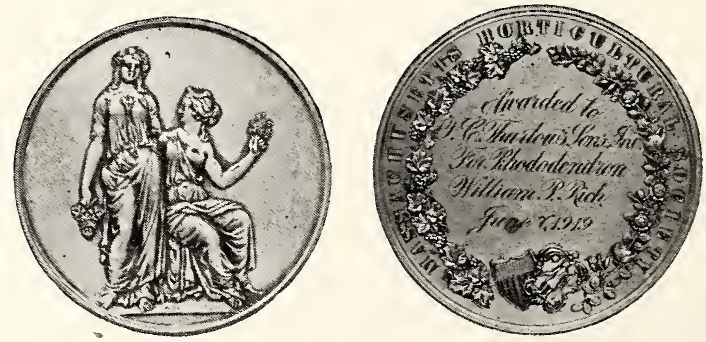

SILVER MEDAL awarded us by Massachusetts Horticultural Society in 1919 


\section{SERIES G}

We have listed in this series the new and rare varieties which include the best productions of this country and Europe. The stock of many varieties is very limited and on some we have placed no price, indicating the scarcity. We shall be glad to advise you by special correspondence of the quantity of these we can furnish.

In the last few years we have introduced a number of fine seedlings at Cherry Hill and these will be found listed in Series H.

ADMIRAL TOGO (Hollis 1907), a very good deep crimson, even color to the tips of the petals. Midseason. $\$ 3.00$ each.

ADOLPHE ROUSSEAU (Dessert \& Mechin 1890), very tall; large dark metallic garnet blooms; on unestablished plants often semidouble. One of the finest of its color. Early midseason. $\$ 2.00$ each.

ALSACE LORRAINE (Lemoine 1906), a very lovely variety having a water-lily effect as the creamy white petals are pointed and the stamens give the flowers a golden halo. Tall and a free bloomer. Late. $\$ 6.00$ each.

AVIATEUR REYMOND (Dessert 1915), light cherry-red with deeper garnet shades at base of petals. $\$ 8.00$ each.

BAYADERE (Lemoine), large globular flowers of creamy-white with a golden heart. When well established it is very fine. Midseason. $\$ 5.00$ each.

BELISAIRE (Lemoine 1901), large cup-shaped flowers of white powdered and sprinkled with lilac, giving a total effect of a delicately tinted flower. Midseason. $\$ 2.50$ each.

BELLE MAUVE (Lemoine 1903), large full flowers of silvery rose. Fragrant, vigorous and a free bloomer. Midseason. $\$ 4.00$ each.

CLEMENTINE GILLOT (Crousse 1885), tall, strong stems bearing large flowers of light crimson. Late.

CORONATION (Kelway), pale pink guard petals changing to white, creamy white center showing golden anthers. Very graceful. Late midseason. $\$ 5.00$ each.

DOCTEUR H. BARNSBY (Dessert 1913), large, very full blooms of crimson with darker shades. Free bloomer in clusters, making a good variety for garden effects. Late. $\$ 5.00$ each.

E. G. HILL (Lemoine 1906), very large flat flowers, imbricated petals, evenly placed; clear rose-pink with occasionally a few golden stamens. Stiff stems of only medium height. Midseason. $\$ 4.00$ each.

E. J. SHAYLOR (Shaylor 1918), clear silvery pink of globular shape, showing stamenoides of yellow edged gold. A very distinct variety. Midseason. $\$ 30.00$ each.

ELIE CHEVALIER (Dessert 1908), large, globular, rather loosely-built flowers of rose-pink; center sometimes flecked with carmine. Tall grower. Midseason. \$2.50 each.

ELWOOD PLEAS (Pleas), very large, delicate pink. Attractive well-formed blooms. Midseason. $\$ 10.00$ each.

ENCHANTERESSÉ (Lemoine 1903), large globular flowers of creamy white with some flecks of carmine. A tall strong grower. Late. $\$ 7.50$ each.

ESTAFETTE (Dessert 1910), large flowers of velvety crimson, shaded amaranth with carmine reflex. Midseason. $\$ 4.00$ each.

ETTA (Terry), extra large semi-flat fiowers of a wonderful shade of deep shell-pink. Extra choice. Late. \$2.00 each.

EUCHARIS (Lemoine), very fragrant, creamy-white flowers of globular shape. Very large when well established. Late. $\$ 6.00$ each.

EUGENE BIGOT (Dessert 1894), a fine bright crimson of upright habit and medium height. One of the best of its color. Midseason to late. $\$ 2.50$ each. 
EUGENE REIGNOUX (Dessert), large, semi-double flowers of rather brilliant pink. Blooms freely in clusters. Midseason. $\$ 2.50$ each.

EVANGELINE (Lemoine 1910), compact flowers of delicate pink sometimes showing flecks of carmine. A very fresh and beautiful flower. Late. $\$ 5.00$ each.

EXQUISITE (Kelway 1912), flat flowers of warm pink, petals pointed, giving a pretty effect. Well established plants produce fine flowers. Fragrant. Midseason to late. $\$ 25.00$ each.

FERDINAND STOLICZKA (Richardson), an early blooming variety bearing flowers of shell-pink with narrow center petals of white. Tall, stiff stems. $\$ 3.00$ each.

FRAICHEUR (Lemoine 1915), exceptionally large flowers of creamy white with delicate shell-pink guard petals. $\$ 10.00$ each.

FRANCES SHAYLOR (Shaylor 1915), globular flowers of glistening white petals interspersed with golden stamenoides. Dwarf plant. Midseason. First prize Am. Peony Society, 1917. Similar in style to E. J. Shaylor. $\$ 20.00$ each.

FRANCOIS ROUSSEAU (Dessert 1909), dark red, yet "with a lustre which makes it noticeable. Medium height. Early. $\$ 4.00$ each.

GALATHEE (Lemoine 1900), very fragrant, soft flesh color or flesh white. Long, stiff stems. Late. $\$ 6.00$ each.

GEORGIANA SHAYLOR (Shaylor 1908), exceptionally large flat flowers of pale rose pink with an occasional crimson fleck. Dwarf habit. Midseason to late. $\$ 15.00$ each.

GERMAINE BIGOT (Dessert 1902), clear cameo-pink with lighter flesh-colored tints in center, broad petals. Midseason. $\$ 2.00$ each.

GINETTE (Dessert 1915), large well-formed flowers of deep flesh with darker salmon tints. Gold stamens are visible and the center petals are occasionally flecked with crimson. Fragrant. We consider this one of the best of the newer French introductions. $\$ 10.00$ each.

GISMONDA (Crousse 1895), globular flowers of creamy white with a rosy light in the center. Fragrant and a beautiful variety. $\$ 4.00$ each.

GLOIRE de TOURAINE (Dessert 1908), globular crimson flowers borne on tall strong stems. Very late. $\$ 3.50$ each.

GRAZIELLA, well formed flowers of flesh-white with canaryyellow tints as flower first opens. Blooms in clusters. Midseason. $\$ 4.00$ each.

GROVER CLEVELAND (Terry), large compact blooms of dark crimson. Very good for garden effects. Late. $\$ 2.00$ each.

H. A. HAGEN (Richardson), one of the best of the Richardson varieties. Deep rose-pink with a few inconspicuous narrow, yellowish petals. Fresh coloring. Very late. $\$ 7.00$ each.

JEANNE GAUDICHAU (Millet), rose-pink bud opening into a large flower with a delicate pink heart, lighter at tips of petals. Very fine. Late. $\$ 6.00$ each.

JEANNOT (Dessert 1918), cup-shaped flower of soft shell-pink slightly tinted violet. Salmon-pink lights at base of petals.
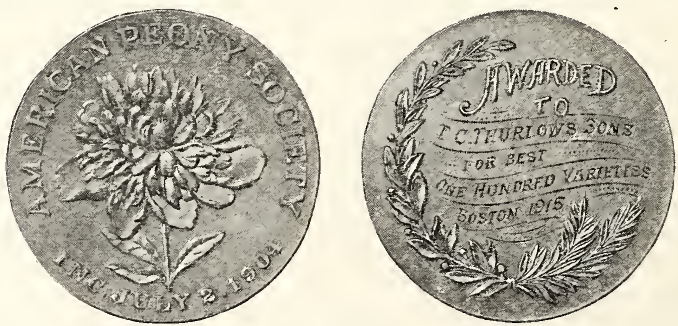

GOLD MEDAL A warded 1915 by the American Peony Society 
JESSIE SHAYLOR (Shaylor 1916), large fragrant flowers of a very pleasing shade of deep cream with golden lights. Midseason. $\$ 20.00$ each.

JOHN RICHARDSON (Richardson), large flat flowers, center of deep rose-pink with silvery lights toward tips of petals. Tall grower; very late. Fragrant. $\$ 5.00$ each.

JUBILEE (Pleas 1908), extremely large flat flowers of ivorywhite, petals long and narrow arranged rather loosely, giving a feathery effect. Midseason to late. $\$ 20.00$ each.

KARL ROSENFIELD (Rosenfield 1908), a very fine brilliant flower of deep crimson. We consider this to be one of the best "red" Peonies in our collection. Midseason. $\$ 5.00$ each.

KELWAY'S GLORIOUS (Kelway 1909), buds slightly tinted pink, opening into large blooms of glistening white. Fragrant. Midseason to late. Won first prize American Peony Society, 1919, for best six blooms, any variety. $\$ 30.00$ each.

KELWAY'S QUEEN (Kelway), large, globular blooms of fine form. Even rose-pink. Fragrant. Midseason. The true variety. $\$ 15.00$ each.

LADY ALEXANDRA DUFF (Kelway), the true variety. Very broad evenly-formed petals keep the immense flowers from appearing coarse. Delicate French pink with soft lights. Before plants are well established stamens are often visible. Midseason. $\$ 15.00$ each.

LA FAYETTE (Dessert 1904), large imbricated blooms with beautifully fringed petals. Rich velvety pink with silvery reflex. Fragrant. Midseason. $\$ 4.00$ each.

LA FEE (Lemoine), globular, compact flowers of rose-pink with a silvery light, creamy-white or straw-colored collar. Fragrant. Early. $\$ 12.00$ each.

LA FIANCEE (Lemoine 1901), very large blooms of creamy white; high crown, sometimes flecked crimson. Strong, vigorous grower. Midseason. $\$ 3.00$ each.

LA FRANCE (Lemoine 1901), enormous, rather flat flowers, evenly formed and very compact. Soft rose-pink, deeper at base of petals. Stems strong and erect. Midseason to late. A very fine variety. $\$ 10.00$ each.

LA LORRAINE (Lemoine 1901), wonderful globular blooms of creamy white, borne high above the foliage, some golden stamens are visible, giving a golden light to the open flower. A charming variety. Midseason to late. $\$ 8.00$ ear:h.

LAMARTINE (Lemoine), full blooms of deep carmine petals tipped white, giving the flowers a silvery light. Tall, strong grower. Late. $\$ 7.50$ each.

LA PERLE (Crousse 1885), the true variety. Blush white, growing darker toward the edge. Fragrant and a charming variety. Late. $\$ 2.00$ each.

LAURA DESSERT (Dessert 1913), yellowish-white guard petals and canary-yellow center. Flower well formed and perhaps the best of the "yellow" Peonies. Very scarce. $\$ 15.00$ each.
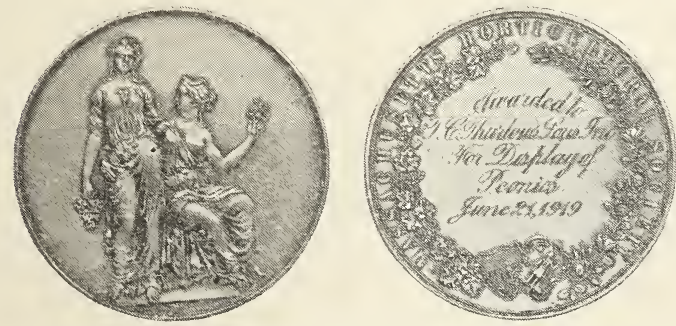

SILVER MEDAL of the Massachusetts Horticultural Society, 1919 
LE CYGNE (Lemoine 1907), exquisite milk-white flowers of large size and perfect shape. Petals broad and silky, stiff stem and dark green foliage. Members of the American Peony Society consider this one of the three best. $\$ 20.00$ each.

LORD KITCHENER (Renault 1916), an early brilliant red. We have not seen the blooms on established plants and cannot give detailed description. $\$ 3.00$ each.

LOVELINESS (Hollis 1907), large flat flowers of hydrangea-pink tinted lighter; blossoms in clusters. Midseason. $\$ 1000$ each.

MADAME AUGUSTE DESSERT (Dessert 1899), beautiful soft rose-pink, fading to flesh color. When flower first opens a ring of golden stamens is visible, which disappears in the fully opened flower. Midseason. $\$ 2.00$ each.

MADAME BOULANGER (Crousse 1886), globular blooms of cameo-pink, oftentimes with accidental carmine markings. The true variety has a delicate and finished appearance and is delightfully fragrant. Late. $\$ 2.50$ each.

MADAME D. TREYERAN (Dessert 1899), delicately tinted white petals dotted and splashed with lilac. A free bloomer and very fragrant. Early. $\$ 4.00$ each.

MADAME FOULD (Crousse 1893), milk-white flowers borne on strong stems. The petals are packed closely together and if given plenty of water will produce very large blooms. Very late. $\$ 2.00$ each.

MADAME GAUDICHAU (Millet 1909), very dark crimson garnet; among the darkest of rare Peonies. $\$ 12.00$ each.

MADAME GUYOT (Pallet), large high-built flowers of white, slightly tinted yellow. Some accidental crimson. Fragrant. Midseason. $\$ 5.00$ each.

MADAME JOANNE SALLIER (Paillet), violet-rose, guards and center flecked crimson.Semi-double blooms of large size. Early. \$5.00 each.

MADAME JULES DESSERT (Dessert 1909), exquisite flowers with broad delicate petals, occasionally showing golden stamens. Petals white but lighted with buff and salmon tints, giving a charming effect. Well formed and a fine flower in every way. Midseason to late. $\$ 8.00$ each.

MADAME MANCHET (Dessert 1913), very full flower of deep rose-pink with a silvery reflex. Very late. $\$ 6.00$.

MADAME SAVREAU (Paillet), bomb type, guard petals and center tinted faint lilac, collar creamy yellow, center petals fiecked scarlet. Early midseason. $\$ 5.00$ each.

MADEMOISELLE JEANNE RIVIERE (Riviere 1908), guard petals deep flesh changing to milk-white, central petals sulphur-yellow. Very vigorous grower and a free bloomer. An especially good variety for garden effects. Midseason. $\$ 5.00$ each.

MARCELLE DESSERT (Dessert 1899), a high-built bloom of creamy white splashed with minute lilac dots, central petals touched with carmine. Sweetly scented. Midseason. $\$ 5.00$ each.

MARGUERITE GAUDICHAU (Millet \& Son), very delicate fringed petals of shell-pink interspersed with yellow petaloids. Large flower and a strong grower. Fragrant. Late. $\$ 10.00$ each.

MARIE CROUSSE (Crousse 1892), globular blooms of delicate shell-pink with salmon tints. A strong grower, the flowers being borne on stiff stems. Fragrant and a fine variety. Midseason to late. $\$ 4.00$ each.

MARQUIS C. LAGERGREN (Dessert 1911), brilliant cherry-red with darker shadings. Flowers evenly formed and borne in clusters on stiff stems. Very good as a garden variety, as the plant is covered with a profusion of blooms. Midseason. \$3.50 each. 
MARY WOODBURY SHAYLOR (Shaylor 1916), guard petals fresh clear pink, creamy yellow center with deeper golden lights. A very fine variety of dwarf upright habit. Midseason. Stock limited. $\$ 35.00$ each.

MIGNON (Lemoine 1908), large globular flowers of amber white, evenly formed and borne well above the light green foliage. Fragrant. Rather dwarf habit. Midseason. $\$ 7.00$ each.

MILTON HILL (Richardson), large blooms of pale salmon-pink or flesh color, sometimes deeply splashed accidental carmine. Very delicate and beautiful coloring. Late. One of the best of the Richardson varieties. $\$ 3.00$ each.

MRS. C. S. MINOT (Minot 1914), a new American variety never before listed. Awarded Silver Medal by Mass. Hortr. Soc. Rather dwarf plant with stiff stems and dark green foliage. Large flowers, perfectly formed, guard petals shell-pink, center pearly white with deeper lights at base of petals and a few splashes of crimson apparent in some flowers. Stock very limited. $\$ 40.00$ each.

M. MARTIN CAHUZAC (Dessert 1899), very dark garnet-the darkest Peony in cultivation. Well established plants produce good-sized globular flowers which are extremely effective. Midseason. $\$ 5.00$ each.

MONT BLANC (Lemoine 1899), one of the largest of Peonies. Very full double flowers of clear white. Petals fringed, giving the flowers the appearance of huge balls. Midseason. $\$ 7.50$ each.

NEPTUNE (Dessert 1905), faint lilac guard petals, center milk white, well formed flowers on strong stems. Midseason. $\$ 2.00$ each.

ODETTE (Dessert 1909), large, bomb-shaped flowers of deep cream color with faint pink guard petals. Tall and a strong grower. Midseason. $\$ 2.50$ each.

PASTEUR (Crousse 1896), delicate shell pink or flesh white, salmon lights at base of petals. Midseason. $\$ 2.00$ each.

PHILLIPE RIVOIRE (Riviere 1911), brilliant garnet of good size and shape. One of the finest varieties of this color. Fragrant. Midseason. Stock limited. $\$ 25.00$ each.

FHYLLIS KELWAY (Kelway), a delicate shade of deep pink with lighter center. A beautiful variety. Midseason to late. $\$ 15.00$ each.

PIERRE DUCHARTRE (Crousse 1895), delicate rose-pink changing to pale pink. Well-formed flowers of large size and symmetrical shape. Plant rather dwarf with stiff stems. Very late. $\$ 2.00$ each.

PIERRE REIGNOUX (Dessert 1908), large loosely-formed flowers of tyrian rose. A tall grower and free bloomer in clusters. Early. $\$ 2.00$ each.

PINK BARONESS SCHROEDER (Kelway), sent out by Kelway in some cases as Baroness Schroeder. Large flat flowers of delicate deep pink. Resembles Jubilee except in color. Midseason to late. $\$ 6.00$ each.

POMPONETTE (Dessert 1909), very full blooms of velvety pink with a silvery reflex; rather dwarf. Midseason. $\$ 2.00$ each.

PRIMEVERE (Lemoine 1907), bomb-shaped blooms of sulphur yellow, guard petals deep cream. Should be picked in bud and opened in water to produce a deep canary yellow. Early midseason. $\$ 5.00$ each.

RAOUL DESSERT (Dessert 1910), very large blooms of shell pink shaded with deeper gleams. Very distinct coloring. Very scarce. $\$ 15.00$ each.

REINE HORTENSE (Calot 1857), beautiful soft flesh color, deepening to shell pink; center showing crimson splashes. Large and well formed. Midseason. $\$ 2.50$ each.

R. P. WHITFIELD (Richardson), flesh, shading a little deeper toward the edge. Rather flat flower and free bloomer. Very late. $\$ 2.00$ each. 
ROSA BONHEUR (Dessert), dwarf plants produce an abundance of large flowers. Fresh, soft pink with incurved petals. Midseason. $\$ 6.00$ each.

ROSETTE (Dessert 1918), delicate shell-pink with salmon lights at base of petals, making tints hard to describe. Some carmine and green markings on guard petals. Flowers produced on young plants show a ring of golden stamens. Early midseason. $\$ 1200$ each.

SAMUEL HENSHAW (Richardson), guard petals clear rosepink tinged with white, center petals white and pink intermixed. Very large full flowers, borne on tall strong stems. Very late. $\$ 5.00$ each.

SARAH BERNHARDT (Lemoine 1906), very delicate, fresh pink coloring. Large well-formed flowers of firm texture and good quality. A very fine variety. Late. $\$ 6.00$ each.

SECRETARY FEWKES (Shaylor 1916), large flowers with broad petals of creamy white with lighter center. Tall and vigorous. $\$ 20.00$ each.

SOLANGE (Lemoine 1907), reddish-golden lights at base of waxy-white petals suffuse this wonderful flower. Large size and perfectly formed. One of the finest in existence. Midseason to late. $\$ 10.00$ each.

SOUVENIR de LOUIS BIGOT (Dessert 1913), large blooms of rich salmon-pink with silvery reflex. Midseason to late. $\$ 7.50$ each.

STANLEY (Crousse 1879), large globular flowers of light pink with lilac lights. Total effect is very pretty. Midseason. $\$ 3.50$ each.

SUZETTE (Dessert 1911), brilliant rose-pink petals interspersed with golden stamens, central petals splashed carmine. Strong stems with a profusion of bloom. Exceptionally fine as a variety for the garden. Midseason. $\$ 4.00$ each.

THERESE (Dessert 1904), probably the most satisfactory Peony, as it is vigorous and free blooming and even on young plants produces large flowers. Soft pink changing to lighter in the center. It is most unusual not to find blooms of Therese among the prize winners at every Peony show. Midseason. $\$ 6.00$ each.

TOURANGELLE (Dessert 1910), cup-shaped flowers of fine form. A very delicate shade of deep cream or buff but with salmon tints which give a total effect of yellowish salmon. Distinct and beautiful. Very fragrant. Late. $\$ 7.50$ each.

VICTOIRE de la MARNE (Dessert 1915), large globular blooms of velvety red with a silvery reflex; bright coloring. Midseason. $\$ 7.50$ each.

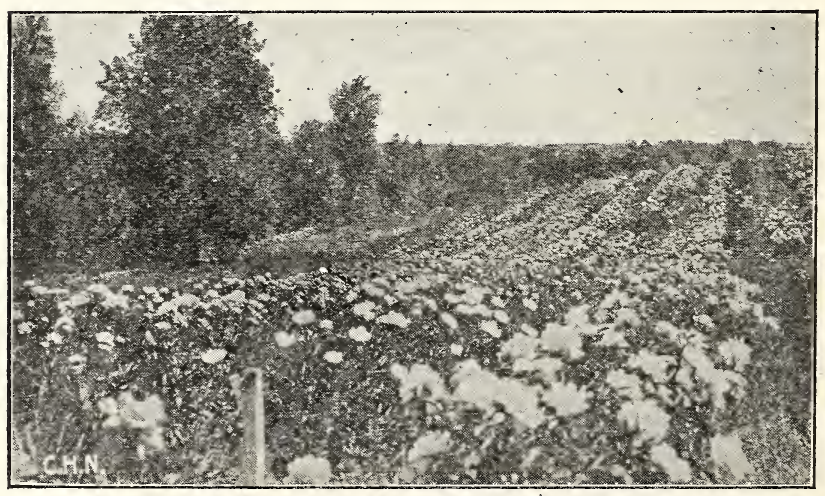


WALTER FAXON (Richardson), medium sized blooms of hydrangea-pink or salmon-pink of a shade seldom seen in a Peony. We consider it to be the best of the Richardson varieties. Late. $\$ 8.00$ each.

WILLIAM F. TURNER (Shaylor 1916), a very dark red or garnet, not quite as dark as M. Martin Cahuzac but a stronger grower. Midseason. $\$ 5.00$ each.

\section{SERIES H}

We are listing below those of our own seedlings which we have placed on the market up to the present time. We have grown hundreds of thousands of seedlings and have studied them carefully, selecting only the few which showed execeptional merit and were distinct from any heretofore produced. We have compared them with the best which we have been able to procure from this country and Europe and betieve that they will stand on their own merits. We will be glad to furnish amplified descriptions of any of these varieties.

A. P. SAUNDERS (1919), large flesh-white flowers changing to nearly pure white in center, guard petals sometimes marked carmine. Petals very long and curved, giving a magnolia bloom effect, except the center petals, which form a ball until flower is well developed. Late. $\$ 20.00$ each.

BLACK PRINCE, single. Very dark garnet of a "flat" tone, not glossy, with a mass of golden stamens. Owing to its soft yet bright coloring this attracts attention whenever exhibited. $\$ 4.00$ each.

CHERRY HILL (1915), very deep garnet, yet with a sheen which makes it especially noticable in a collection; in blooms not fully developed stamens are visible. Stems long, from four to four and a half feet, and very erect. It shows at its best in the garden where the glowing flowers are visible from a distance. Awarded Silver Medal by Mass. Hort. Society. $\$ 25.00$ each.

EDWIN C. SHAW (1919), clear rose, slightly lighter at tips of petals. Outer petals broad and imbricated and extreme center petals much shorter. No traces of carmine are visible. A beautiful flower, both in color and form. Midseason. $\$ 35.00$ each.

JAMES BOYD (1919), flesh, changing to nearly white, tinted at base of petals with yellowish salmon. Guard petals sometimes touched with carmine and green. Petals notched at tips, giving a fringed effect. Fragrant. Late. $\$ 20.00$ each.

JAMES R. MANN (1920), large, deep, rosy pink, with one or two crimson streaks in the center of the flower and an occasional marking on back of guard petals. Central petals incurved, giving a very graceful effect. $\$ 30.00$ each.

NYMPHAEA (1919), large, flat flowers with wide silky petals of delicate creamy white, notched at tips, and edges somewhat rolled; yellow stamens in center and a reflex of golden light throughout whole flower. Midseason. $\$ 15.00$ each.

PRESIDENT WILSON (1918), soft rose-pink changing to shellpink as flower opens, guard petals sometimes show crimson markings. Center petals very short, somewhat laciniated, gradually increasing in length outward, producing a cuplike effect. Fragrant. Late. $\$ 50.00$ each.

PRIDE OF ESSEX (1916), exceptionally broad petals of deep flesh-pink make a very large flower of good form. Stems long and stiff. Midseason. First Class Certificate Mass. Hort. Snc. $\$ 15.00$ each. 
THOMAS C. THURLOW (1919), salmon-flesh changing to white. Guard petals broad and collar of narrower petals or broad petaloids tinted and edged yellow, giving a delicate coloring. The extreme center is made up of short yellow petaloids surrounded by a ring of cup-shaped petals edged yellow. Midseason. $\$ 50.00$ each.

WINNIKENNI, very full blooms of cherry-pink, tall and vigorous grower and bears a profusion of flowers. Buds very tight and sometimes inclined to burst. Very late. $\$ 4.00$ each.

We are listing below a number of varieties originated by Mr. Brand of Minnesota. They have attracted much favorable comment in the West, and we have secured and planted in our gardens all the varieties here listed. They have a wide range of color and we believe will find their way into many collections. In most cases we give originator's descriptions.

ARCHIE BRAND (1913), large, beautifully formed, shell pink with lighter border. $\$ 10.00$ each.

BENJAMIN FRANKLIN (1907), deep bright red, medium size. Stems long and straight. $\$ 2.00$ each.

CHARLES MCKELLIP (1907), large size, rich bright red. $\$ 5.00$ each.

CHESTINE GOWDY (1913), shell pink with cream colored collar. $\$ 5.00$ each.

ELIZABETH BARRETT BROWNING (1907), very fine flossy white of large size. Late. $\$ 25.00$ each.

ELLA WHEELER WILCOX (1907), deep pink of noticeable fragrance. Blossoms in clusters. $\$ 3.00$ each.

FARIBAULT (1918), deep rose of a peculiar shade with a silver sheen. $\$ 10.00$ each.

FLORENCE NIGHTINGALE (1907), dainty white. Among the very latest. $\$ 5.00$ each.

FRANCES WILLARD (1907), tall, strong grower, producing creamy white flowers of large size, yet delicate texture. One of the best of the Brand seedlings. $\$ 10.00$ each.

HARRIET FARNSLEY (1916), beautiful shell pink. Late. $\$ 5.00$ each.

HENRY AVERY (1907), white with some accidental markings of yellow and green in the center. Very fragrant. $\$ 10.00$. each.

JUDGE BERRY (1907), delicate pink, flat flowers of large size. Very early. $\$ 10.00$ each.

LONGFELLOW (1907), pronounced by its originators the brightest red Peony in existence. $\$ 10.00$ each.

LORA DEXHEIMER (1913), another red of much the same shade as Louis Van Houtte, only larger. $\$ 5.00$ each.

MARTHA BULLOCH (1907), considered the best of the Brand Peonies. Tall, strong grower, producing immense blooms of soft rose pink, well formed and of good substance. $\$ 25.00$ each.

MARY BRAND (1907). Mr. Brand has produced a good many red Peonies and he considers this to be the best one of this color. $\$ 15.00$ each.

MIDNIGHT (1907), large, very dark maroon; good for cut flowers. Early midseason. $\$ 3.00$ each

MRS. CAREW (1907), delicate, silvery blush, some inner petals with carmine edges. Very fragrant. $\$ 5.00$ each.

OLD SILVER TIP (1918), soft madder-red with silver tipped petals giving a silvery sheen. Stiff stems and good foliage. Late. $\$ 10.00$ each.

PHOEBE CAREY (1907), petals large, broad and of good substance. Color a beautiful rose pink with center slightly deeper in shade. Tall grower. Late. $\$ 10.00$ each. 
PRINCE of DARKNESS (1907), an exceptionally dark maroon, one of the darkest of Peonies. Early. $\$ 2.00$ each.

Cahuzac. Early. $\$ 2.00$ each.

RICHARD CARVEL (1913), very early, deep red. In bloom with Edulis Superba. Fragrant. $\$ 6.00$ each

RUTH BRAND (1907), large, compact bomb-type of soft lavender pink. Strong stems. Midseason. $\$ 3.00$ each.

WINNIFRED DOMME (1913), medium size, brilliant dark red. Medium early. $\$ 5.00$ each.

\section{PHLOX}

These popular perennials should be accorded a place in every garden as they are easy to cultivate and produce wonderful results. Their many varied tints allow one to make a multitude of combination plahtings along with other hardy perennials.

To obtain the best results they should be divided and reset every fire or six years or oftener if crowded.

Sometimes, in an especially wet season, there is a tendency for the lower leaves to mildew. This can be prevented by dusting dry sulphur on them or by using Bordeaux mixture.

It is considered good practice to cut off the blooms before they go to seed, thus preventing the growth of small seedlings, which should always be destroyed, as they will often grow to such an extent that they will choke the parent plant.

\section{SERIES A}

\section{0 cents each ; $\$ 2.00$ per doz; $\$ 15.00$ per hundred}

Six of a variety at the dozen rate, and 50 of a variety at the hundred rate. Double-size clumps at double price.

ANTONIN MERCIE, a tall variety of a beautiful shade of lavender, eye white. Midseason.

ECLAIREUR, a medium height variety bearing a good sized truss of pansy-purple flowers with a lighter center. Early midseason.

LE FEU DE MONDE, a tall variety, excellent for massing, bright crimson red with darker center. Midseason.

LE POLE NORD, a fine tall late-blooming phlox that gives good results. Ivory-white with a large crimson eye.

MME. PAPE-CARPENTIER, a medium growing variety, producing large trusses of waxy-white blossoms. Extra. Midseason.

MISS LINGARD, one of the earliest flowering tall varieties. Medium sized white flower with light red eye. A continual bloomer.

RICHARD WALLACE, a tall, pure white, with violet-red eye. Always has a clear-cut and tidy appearance. Midseason.

SAISON'S LIERVAL, tall, clear white with small red eye. One of the old-fashioned varieties but always acceptable. Iate midseason.

STELLA'S CHOICE, a tall vigorous grower. Trusses very large and snow-white. Extra nice. Late. 


\section{SERIES B}

25 cents each ; $\$ 2.50$ per doz; $\$ 18.00$ per hundred

Six of a variety at the dozen rate and 50 of a variety at the hundred rate. Double size clumps at double price.

ARETE, white with crimson eye, fresh and pleasing. Medium height. Midseason.

COQUELICOT, a noticeable bright vermilion with small purple eye. Medium height. Midseason.

EUGENE DANZANVILLIERS, a choice variety bearing large trusses of soft lavender with lighter-tinted center. Medium height. Midseason to late.

EUROPA, a pleasing variety of medium height with ivory-white blooms and carmine eye. Trusses large and well formed. Midseason.

F. G. VON LASSBURG, plants of medium height, bearing pure white trusses of good size and substance. Individual panicles extra large. Midseason.

GEN. VAN HEUTZ, large panicles of salmon-red on medium sized trusses. Eye a grayish-white. Midseason to late. Tall.

HANNY PFLEIDERER, a beautiful velvety white, overlaid with light rose-pink with carmine eye, flowers large, medium height. Midseason.

INDEPENDENCE, a tall vigorous growing white of fine shape and quality. Early.

JEANNE d'ARC, another tall white, bearing large trusses of waxy white flowers in abundance. Midseason.

LANIBOIRE, rosy scarlet with darker center, free blooming and trusses of good size. Tall. Midseason to late.

LE MAHDI, about the best dark blue phlox grown. Flowers large, plants tall. Late.

LE SOLEIL, beautiful soft rose with darker-shaded eye, very choice. Medium height. Abundant bloomer during July, August and September.

MR. GLADSTONE, a tall growing variety of a beautiful satiny rose with darker center. Midseason.

MONS. GRAHAM, a profuse bloomer of bright rose-pink. Medium height. Midseason to late.

PANTHEON, a somewhat lighter rose-pink than Mons. Graham. Very choice. Tall. Medium to late.

PEACH BLOW, as its name implies, this variety is practically a peach-blosom pink with a somewhat lighter eye. Plant somewhat dwarf. Midseason.

PINK BEAUTY, a bright clear pink of medium sized flowers. Tall. Midseason.

\section{SERIES C}

35 cents each $; \$ 3.00$ per doz; $\$ 22.00$ per hundred

Six of a variety at the dozen rate and 50 of a variety at the hundred rate. Double size clumps at double price.

ASIA, one of the newer varieties, a beautiful lilac-rose with brilliant carmine eye. Medium height. Midseason to late.

BARON VON DEDEM, a rich satiny blood-red with large attractive panicles. Truss of good size. Medium height. Midseason.

BERENICE, a medium growing ivory-white of good size and vigor. Considered extra choice. Midseason.

CAMERON, an exquisite shade of deep apple-blossom pink, one of the best ever offered. Trusses of medium size with panicles large. Medium height. Midseason to late.

ELISABETH CAMPBELL, too much praise cannot be given this most popular variety. Large individual salmon-pink panicles on good-sized trusses, very distinct. Plant medium. Midseason to late. 
FRAU ANTON BUCHNER, a rich creamy-white blossom of extra size panicle and truss. Medium to tall. Midseason.

LE CYGNE, an extra good bloomer, large trusses of rich waxy white blossoms. Medium height. Midseason.

MME. PAUL DUTRIE, a strong bloomer of exquisitely shaded apple-blossom pink, lighter toward the center. Medium. Midseason.

MAID MARIAN, one of the best of our own seedlings, an ideal soft lavender, very even in its color. Fanicles are extra large. Midseason.

MRS. OLIVER, a rich salmon-pink with lighter center, very sprightly. Medium height. Midseason.

MARQUIS de ST. PAUL, a tall clear salmon-pink with darker eye. One of the best. Medium sized trusses. Midseason.

RYNSTROOM, an exceptionally beautiful brilliant rose blossom large size and truss. Tall. Midseason to late.

SELMA, large trusses of a rich hydrangea-pink with carmine eye, a strong bloomer. Tall. Midseason to late.

TAPIS BLANC, a dwarf white of value. Trusses and panicles large and elegant. Midseason.

WIDAR, a deep violet-blue with pure white eye. Medium. Midseason.

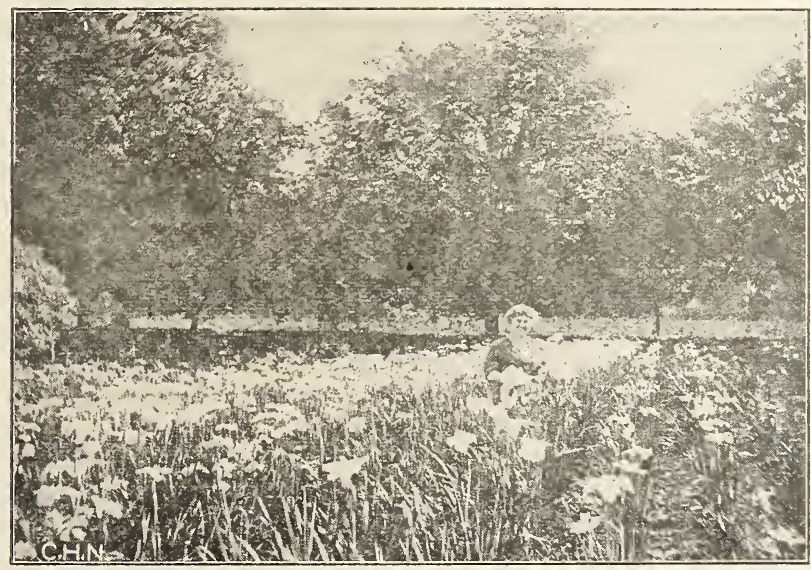

A VIEW OF OUR JAPANESE IRIS IV BLOOM

\section{JAPANESE IRIS-IRIS KAEMPFERI}

This Iris is the last of the family to bloom and its wonderful blossoms are a fitting climax to the beauties displayed by the other sorts. In a farorable location plants will attain shoulder height and produce flowers eight and even ten and twelve inches across. To do this they should be planted in a well-drained spot, so that water will not freeze around the roots in winter, and given plenty of water as the buds are opening in July. Leaf-mold worked into the soil is rery good, as it acts like a sponge and retains the moisture in the summer.

Two or three years ago we imported a good many varieties of Iris from Japan, and have a fine collection of colors and varieties. 
We can furnish the following, which we have listed under numbers, as the names are so cumbersome, but keep a record of the names for those desiring them;

\section{Price 35 cents each, \$3.00 per dozen.}

TOKIO, six petals; bluish violet, heavily overlaid with wide veinings of white. A hardy, tall growing variety.

No. 7 , six petals; blue violet with white veins radiating from the golden throat.

No. 9, three petals; deep violet, heavily overlaid with grey veinings, producing a tinted grey effect. S. grey bordered violet.

NO. 50, three petals; large, deep violet with intense lights near base of petals contrasting with deep yellow throat. Anthers grey, tipped violet.

NO. 51, six petals; large flower of glistening white with yellow throat, standards divided, of tentimes extra petaloids appearing. Flower stems often five feet tall.

NO. 52, nine petals, owing to standards having developed into narrow petals. Reddish plum, veined grey at throat.

NO. 101, three petals; tall narrow foliage and stems bearing violet-red flowers. Very early and free bloomer.

No. 102, three petals; greyish white, royal purple veinings; narrow neck with golden throat. $S$. reddish purple with white tips.

No. 107, six petals; royal purple fading to a soft blue in the fully opened flower.

NO. 118 , three petals; pure white with golden-yellow throat.

NO. 132, six petals; bright velvety violet. S. pearly white. Very distinct from rest of flower.

NO. 134, three petals; grey field overlaid with red violet deepening at edges of petals; yellow throat. S. white tipped red violet.

NO. 142, six petals; deep violet with yellow throat; S. grey tipped violet and tufted, giving a very pretty effect.

No. 147, three petals; dusky purple minutely flecked grey, yellow throat. Secondary petals same color, not flecked. S. grey, edged and tipped purple.

NO. 149, six petals; greyish-white clouded lavender and veined light blue. S. deep lavender. Large.

No. 150, three petals; red violet, veined gray; yellow throat.

No. 152, six petals; deep blue violet, yellow throat. S. tufted.

NO. 158, six petals; very double; deep blue with rich yellow throat; S. white tipped deep blue and tufted.

NO. 159, six petals; beautiful reddish plum; noticeable yellow throat and $\mathrm{S}$. deep plum, tufted.

\section{FLEUR-DE-LIS-LILY OF FRANCE}

These beautiful flowers have been well called by some "Rainbow Flowers," for there is no shade or tint but what may be found in some measure among them.

The blossoming season usually opens with the dwarf Pumilas about the last of April and continues through May and early June, finishing up with the Siberian varieties.

Iris may be planted in any well-drained soil and with safety almost any time when the ground is not frozen, but to secure the best results they should be put in the soil eitlier in April or after the first of August.

Plant the tubers or roots so that they will be about one inch below the surface and put well rotted manure or fertilizer on the surface and rake it lightly in. 
The following varieties have undergone the testing-out process and can be heartily recommended as among the best.

In the descriptions given $\mathrm{S}$ signifies standards and $\mathrm{F}$ indicates falls.

\section{SERIES A}

\section{Flowering plants, 15 cents each ; \$1.50 per dozen $\$ 12.00$ per hundred.}

Six of a variety at the dozen rate and 50 of a variety at the hundred rate. Double size clumps at double price.

EDITH, a bountiful bloomer and very desirable for a border. S. white, F. clear deep lavender. Height 24 to 30 inches.

GOLIATH, a good bloomer of pleasing color. S. lavender, F. white with purple veinings. Height about 21 to 24 inches.

JOHN BRIGHT, S. and F. reddish violet. Plant about 18 inches high.

MISS MAGGIE, S. and $F$. soft pinkish lavender, very nice. Height about 21 to 24 inches.

PUMILA varieties, height about 5 inches. Light blue, dark blue, white, royal purple.

SIBIRICA ORIENTALIS, rich deep blue, very attractive in the opening bud. Blooms about mid-June. Height about 42 inches.

VAN GEERTII, a charming variety with $\mathrm{S}$. dusky lavender and $F$. a dark violet with white veinings and orange crest. Height 21 to 24 inches.

VIRGILE, a low-growing variety and free flowering. S. bronze, F. purple.

\section{SERIES B}

Flowering clumps, 25 cents each ; $\$ 2.50$ per dozen $\$ 15.00$ per hundred except as noted.

Six of a variety at the dozen rate and 50 of a variety at the hundred rate. Double-size elumps double price.

APHILLA, height, 30 inches. S. and F., white, fringed purple.

AUREA (Variegata), height, 24 inches. 35 cents each; $\$ 3.00$ per dozen. S. and F., rich, orange yellow.

CRIMSON QUEEN, height, 24 inches, very dark reddish plum. A fine shade which is very attractive. 75 cents each.

CYPRIANA SUPERBA, height, 18 inches. $\mathrm{S}$. and $\mathrm{F}$., fine royal purple; large flower.

DR. BERNICE, height, 30 inches. S., coppery bronze; F., rich velvety plum; extra.

ELEGANS, height 30 inches. S., white shaded bluish lavender F., reddish plum.

FAIRY, height 30 inches; white, sometimes delicately shaded lavender. Branching habit bearing quantities of flowers. 35 cents each; $\$ 3.00$ per dozen.

FLAVESCENS, height 30 inches. S. and F., a delicate shade of soft yellow; prolific bloomer. Very good for borders.

FLORENTINA ALBA, height 18 to 24 inches. White; very early and vigorous; valuable for cut flowers.

GLORY OF READING, height 30 inches. S., deep blue; F., rich royal purple with a conspicuous orange beard. 75 cents each.

GRACCHUS, height 18 inches. S., clear yellow; F., maroon red, reticulated white.

GYPSY QUEEN, height 36 inches. S., bright coppery crimson; F., rich dark maroon.

HALFDAN, height 24 incnes. Very faint yellowish white. S. and F., self color with yellow beard. Very early. 50 cents each. 
H. CRAMER, height 24 inches. S., pale lavender; F., a little darker.

HECTOR, height 30 inches. S., soft clouded yellow; F., rich violet red; very showy. 50 cents each.

HER MAJESTY, height 24 inches. 35 cents each; $\$ 3.00$ per dozen. S., old rose; F., white, striped rosy lilac. Very large flower.

INGEBORD, height, 15 inches. Light straw color, nearly white with light yellow beard. Early. 50 cents each.

IROQUOIS, height 24 inches. S., clouded lavender dotted brown. F., very dark plum reticulated white. Unique. 50 cents each.

IRIS AUREA (specie), clear bright yellow, blooming between the Siberian and Japanese species. 35 cents each; $\$ 3.00$ per dozen.

IRIS KING (new), height 30 inches. S., rich yellow; F., velvety plum edged yellow. A very striking variety. 50 cents each.

JUANITA, height 36 inches. Clear blue with tall stems and large flowers. Very fine. 50 cents each.

KHARPUT, height 24 inches. Very large; rich royal purple; extra.

LOHENGRIN, height 36 inches. A beautiful shade of old rose. A vigorous grower, producing large flowers in abundance. $7 j$ cents each.

LORD WOLSELEY (Monspur), height 36 inches. A new hybrid blossoming in the latter part of June. Narrow foliage and light blue flowers.

LORELEY, height 24 inches. S., light yellow; F., ultramarine blue, bordered cream. 75 cents each.

MADAME CHEREAU, height 3 to 4 feet. Pure white, edges beautifuly penciled azure; superb.

MADAME PACQUITTE, height 30 inches. S. and F., bright rosy claret; late.

MISS E. EARDLEY, height 24 inches. S., creamy yellow. F.. blue bordered cream. 50 cents each.

MRS. H. DARWIN, height 24 inches. White; F., slightly reticulated riolet at base; extra.

MRS. NEUBRONNER, height 24 inches. Deep golden yellow; one of the best of this color. 50 cents each; $\$ 5.00$ per dozen.

MONSEIGNEUR, height 30 inches. S., rich violet; F., darker. Very rich coloring. New, $\$ 1.00$ each.

MONTEZUMA, height 24 inches. S., golden yellow dotted brown at base. F., white, clouded yellow and veined rich brown, especially on the throat. Very delicate and fine. Not for sale.

MT. PENN, height 30 inches. S., violet red. F., deeper with rich coloring. Not for sale.

PALLIDA AUSTRALIS, height 36 inches. S., deep lavender. F., soft blue. Very handsome.

PALLIDA DALMATICA, height 36 inches. A much sought variety with strong, broad leaves and wide petaled lavender flowers. The true variety is very scarce both in this country and Europe.

PALLIDA SPECIOSA, height 3 to 4 feet. We formerly listed this under the name of $P$. Dalmatica, but this variety is taller and, we think, more effective than the latter in mass plantings. It has the broad foliage of the Pallida varieties and lavender flowers borne four or five on a stalk.

PFAUENAUGE, height 24 inches. S., rich yellow. F., velvety plum color bordered deep yellow. 75 cents each.

PRINCESS VICTORIA LOUISE, height 30 inches. S., pale yellow; F., rich violet edged creain. Very fresh coloring and especially attractive in the garden. 75 cents each.

QUEEN OF MAY, height 30 to 36 inches. Delicate old rose; early.

ROSE UNIQUE, height 24 inches. Very bright old rose, the nearest to clear pink of any Iris we have seen. 75 cents each. 
SNOW QUEEN (SIberica), helght 42 inches. Pure white. This is a variety of the Siberian Iris which blooms a little later than the German Iris.

TECUMSEH, height 36 inches. S., clouded yellow or buff; F., reddish plum. 50 cents each.

THORBECK, height 12 inches. S., white, sometimes marked blue; F., rich clear blue. 35 cents each.

WALHALLA, height 20 inches. S., deep lavender; F., plum color. Early. 50 cents each.

WALNERIANA, height 30 inches. S., light blue, flushed bronze; F., pale violet; orange crest.

WINDHAM, S. soft lavender pink. F. heavily veined darker. Large flower. $\$ 1.00$ each.

\section{HERBACEOUS PLANTS}

We do not attempt to carry a long line of perennials, but our aim has been to grow the BEST, both in variety and in the size of the plants. In many cases we can furnish strong clumps which will produce an immediate effect and give color to the perennial border throughout the season.

Sometimes certain varieties are superior to the type and we have discarded those which have not distinct coloring and free blooming habits.

Some varieties are very scarce, as the foreign supply has been cut off, and these varieties we are able to furnish in small quantities only, for this season.

We have, many times, plants in our gardens which are not listed, and would be glad to advise you by special correspondence if certain articles are desired.

ACHILLEA PTARMICA FL. PL. "THE PEARL." (Yarrow). Rosette-shaped flowers of pure white are produced in profusion practically all summer. 2 feet.

ACONITUM AUTUMNALE. (Monkshood). These tall spikes of dark blue flowers will do well in a shady place, although they should not be planted where roots or trees will sap the ground. August and September. 4 feet.

ACONITUM NAPELLUS BI-COLOR. Blue and white flowers. Very pretty. August and September. 4 feet.

AGROSTEMNA CORONARIA. (Mullein Pink). Ornamental foliage of a "woolly" appearance and velvety carmine flowers. June and July. 2 to 3 feet.

ALTHAEA ROSEA. (Hollyhock). Tall spikes of single and double flowers, ranging from white to dark maroon. July to September. 6 to 8 feet.

ALYSSUM SAXATILE COMPACTUM. (Gold Tuft). Small clusters of bright yellow flowers. Very useful for rock work. 8 to 12 inches. May.

ANCHUSA ITALICA DROPMORE. Bright blue flowers. 3 to 5 feet. May and June.

ANEMONE JAPONICA. (Japanese Windflower). Beautiful rosy red or carmine flowers with yellow stamens. Fall flowering. 2 to 3 feet.

ANEMONE JAPONICA ALBA. (Handsome white flowers with yellow stamens. September. 2 to 3 feet. $25 \mathrm{c}$ each; $\$ 2.50$ per doz.

ANEMONE, PRINCE HENRY. Rich double pink. Fall. 2 to 3 feet.

ANEMONE, QUEEN CHARLOTTE. Deep apple blossom pink, semi-double. 2 to 3 feet.

Prices for perennials, unless otherwise noted, are 25 cents each; $\$ 2.50$ per dozen. Six of a variety at the dozen rate. Extra large clumps charged according to size. 
ANEMONE, WHIRLWIND. Pure white, semi-double flowers. 3 to 4 feet. $25 \mathrm{c}$ each; $\$ 2.50$ per doz.

AQUILEGIA CANADENSIS. (Columbine). Bright scarlet and yellow flowers. 12 to 15 inches. May and June.

AQUILEGIA, LONG-SPURRED HYBRIDS. New large-flowering strain. Blossoms of exquisite shades. 18 to 24 inches. May and June.

AQUILEGIA NIVEA GRANDIFLORA. Beautiful pure white flowers. 18 to 24 inches.

AQUILEGIA CHRYSANTHA. Yellow with claret-tinted tip. Excellent. 18 to 24 inches.

ARABIS ALPINA. (Rock Cress). Pure white, dwarf. May. 6 to 12 inches.

ASTER, NOVAE-ANGLIAE. (New England Aster). Cerulean blue flowers. 3 to 5 feet. September and October.

ASTER NOVAE-ANGLIAE ROSEA. Beautiful soft rose-colored flowers. 3 to 5 feet.

ASTER NOVI-BELGI. Pale blue flowers, not quite as tall as the novae-angliae.

ASTILBE JAPONICA, GLADSTONE. (Japanese Spirae). Fine white flowers, in large pyramidal heads. June and July. 2 feet.

ASTILBE, QUEEN ALEXANDRA. Soft pink hybrid. New. Very handsome. 30c each; $\$ 3.00$ per doz.

BOCCONIA CORDATA. (Plume Poppy). Unique buff flowers. Valuable for screen and foliage. 5 to 8 feet. July and August.

BOLTONIA ASTEROIDES. (False Chamomile). Daisy-like flowers in great abundance. 5 to 7 feet. September and October.

CAMPANULA CARPATICA. (Carpathian Harebell). Beautiful large, deep blue flowers. 12 inches. June to September.

CAMPANULA MEDIA. (Canterbury Bells). Bell-shaped flowers, dark blue, light blue, white, and rose. Biennial. 2 to 3 feet. July and August.

CAMPANULA PERSICIFOLIA GRANDIFLORA. Large, deep blue, salver-shaped flowers. 2 feet. July and August.

CAMPANULA FERSICIFLORA ALBA. A pure white variety of the above.

CAMPANULA CALYCANTHEMA. (Cup and Saucer). Self colors, rose, blue, and white. 2 to 3 feet. July and August.

CHRYSANTHEMUM, SHASTA DAISY. Large white blossoms, 3 to 4 inches across, yellow centers. 15 to 18 inches. September and October.

CHRYSANTHEMUM, HARDY POMPON. Strong, hardy plants in yellow, white, bronze, and pink. 3 to 4 feet. November.

CONVALLARIA MAJALIS. (Lily of the Valley). Delicate maxy white flowers. 6 to 10 inches. May. Clumps, 50c each; $\$ 5.00$ per doz.

COREOPSIS LANCEOLATA. (Tick Seed). Bright goldenyellow single flowers. June to September. 2 to 3 feet.

DELPHINIUM BELLADONNA. (Larkspur). Beautiful blue flowers, free blooming. Dwarf habit. 30c each; $\$ 3.00$ per dozen.

DELPHINIUM CHINENSIS. Delicate light blue flowers. 12 to 15 inches. July to September.

DELPHINIUM CHINENSIS ALBA. A white form of the above. DELPHINIUM ELATUM. Dark blue. 3 to 6 feet. June to September.

DELPHINIUM HYBRIDUM. Superb strain, flowers varying from lightest to darkest blue. 5 to 6 feet. June to September.

Prices for perennials, unless otherwise noted, are 25 cents each; $\$ 2.50$ per dozen. Six of a variety at the dozen rate. Extra large clumps charged according to size. 
DIANTHUS BARBATUS. (Sweet William). Iarge flat heads of flowers in scarlet, white, maroon, and pink. Entire season. 12 to 15 inches.

DIANTHUS PLUMARIUS. (Old-fashioned Garden Pink). Light, silvery foliage, flowers in various shades, from fleshwhite to deep pink. 12 to 15 inches. May to July.

DICENTRA SPECTABILIS. (Bleeding Heart). Peculiar, heart-shaped pink and white blossoms borne in long racemes. 2 feet. May to June. 50c each; $\$ 5.00$ per doz.

DICTAMNUS FRAXINELLA. (Burning Bush). Very bushy plants, bearing peculiar red flowers, balsam scented. 2 to $21 / 2$ feet. June and Jily. $30 \mathrm{c}$ each; $\$ 3.00$ per doz.

DIGITALIS. (Foxglove). Large, woolly-leaved biennial bearing enormous spikes of showy flowers in many colors. 3 to 4 feet. June to September.

FUNKIA COERULEA. (Blue Day-Lily). Light blue flowers, foliage large and of tropical appearance. 18 to 24 inches. July to August.

FUNKIA SUBCORDATA. (White Day-Lily). Large, pale green, tropical foliage, bearing waxy-white flowers. 18 to 24 inches.

FUNKIA VARIEGATA. Variegated foliage, very showy, dwarf. 6 to 12 inches.

GAILLARDIA GRANDIFLORA. (Blanket Flower). Large crimson and gold flowers. Very showy. 18 to 24 inches. July to October.

\section{GLADIOLI}

Strong flowering bulbs. No. 1 size.

AUGUSTA. Ivory white with light blue anthers. Very choice. $75 \mathrm{c}$ per $12 ; \$ 4.50$ per 100 .

AMERICA. One of the best. Flowers an exquisite shade of pink and quite large. $75 \mathrm{c}$ per $12 ; \$ 4.50$ per 100 .

BARON HULOT. Rich deep blue, the best of its color known. $90 \mathrm{c}$ per $12 ; \$ 6.50$ per 100.

BRENCHLEYENSIS. Bright vermilion. Very good for planting among shrubbery. 60c per $12 ; \$ 3.50$ per 100.

EMPRESS OF INDIA. Dark blackish-red. Very rich and velvety in appearance. $\$ 1.50$ per $12 ; \$ 8.00$ per 100 .

FANCY HYBRIDS. Very free flowering and rich in their colorings. $60 \mathrm{c}$ per $12 ; \$ 4.00$ per 100 .

GLORY OF HOLLAND. New, white with a slight tinting of pale pink, anthers of delicate lavender. $\$ 1.50$ per 12; $\$ 11.00$ per 100 .

GOLDEN WEST. Clear, orange-scarlet, with lower petals blazed with golden yellow and violet shadings. $\$ 2.50$ per $12 ; \$ 20.00$ per 100.

GOLDEN QUEEN. Clear-cut cream color, with diamondshaped blotch of carmine; will not fade. $\$ 1.25$ per 12 ; $\$ 8.00$ per 100 .

INDEPENDENCE. Clear flame color. 75c per 12; $\$ 5.00$ per 100.

KUNDRED'S GLORY. Delicate pink with creamy buff shading, ruffled petals; very fine for display. $\$ 1.50$ per 12 ; $\$ 9.00$ per 100 .

LILY LEHMAN. Pure, glistening white, with a faint tinge of pink on the tips of the petals. $\$ 1.50$ per $12 ; \$ 10.00$ per 100 .

Prices for perennials, unless otherwise noted, are 25 cents each; $\$ 2.50$ per dozen. Six of a variety at the dozen rate. Extra large clumps charged according to size. 
MRS. FRANCIS KING. Bright flame-pink, large flowers. 75c per $12 ; \$ 4.50$ per 100 .

MRS. FRANK PENDLETON. Clear, soft rose-pink, one of Mr. Kunderd's best. $\$ 1.50$ per $12 ; \$ 10.00$ per 100 .

NIAGARA. Clear, delicate yellow of a pleasing tint. $\$ 1.25$ per $12 ; \$ 9.00$ per 100 .

PANAMA. A variety somewhat deeper and larger than America and much better. $\$ 1.25$ per $12 ; \$ 9.00$ per 100 .

PEACE. Large, beautiful white flowers, with pale lilac feathering on inferior petals. $\$ 1.25$ per $12 ; \$ 8.00$ per 100 .

PRINCEPS. Dazzling scarlet of extra size, plants somewhat dwarf. $\$ 1.25$ per 12 ; $\$ 8.00$ per 100 .

SCHWABEN. New. One of the largest and best of the yellow, with royal purple tongue on lower petals. $\$ 1.50$ per $12 ; \$ 11.00$ per 100 .

SULPHUR KING. Clear sulphur-yellow, considered the best of all the yellows. Rewarded the Certificate of Merit in Holland, 1912 and 1913 . $\$ 3.00$ per 12 .

SUMMER BEAUTY. Hanđsome deep pink, with crimson throat; quite early. $\$ 2.50$ per $12 ; \$ 18.00$ per 100 .

HELENIUM AUTUMNALE. (Sneezewort). Bright yellow flowers. August and September. 4 to 6 feet.

HELENIUM AUTUMNALE RUBRUM. New, bright terracotta flowers. August and September. 3 to $4 \frac{1}{2}$ feet.

HELIANTHUS MOLLIS, (Sunflower). Bright lemon-yellow flowers. 5 feet. July and August.

HEMEROCALLIS, GOLD DUST. (Yellow Day-Lily). Bright orange-yellow, with buds and reverse side of petals handsome golden bronze. May and June. $2 \frac{1}{2}$ feet.

HEMEROCALLIS FLAVA. (Lemon Lily). Bright, single yellow flowers, foliage long and narrow. 2 feet. June.

HEMEROCALLIS KWANSO FL. PL. Double; orange-yellow with deep red spots. July. 2 to $2 \frac{1}{2}$ feet.

HEMEROCALLIS DUMORTIERI. Very dwarf. 18 inches. Rich golden yellow. June.

HEMEROCALLIS MINOR. Clear yellow flowers, appear in June, fine foliage. 18 inches.

HEUCHERA SANGIUINEA. (Alum Root). Bright crimson flowers; good for cutting. June to September. 1 to 2 feet.

HIBISCUS MOSCHEUTOS. (Mallow). Single white flowers with crimson center. 4 to 6 feet. August.

IBERIS SEMPERVIRENS. (Hardy Candytuft). Numerous flat, snow-white flowers. Very pretty. 9 to 12 inches. May and June.

IRIS. See our special catalog, wherein you will find listed many of the choicest varieties grown.

LAVENDULA VERA. (Sweet Lavender). Fragrant lavender flowers with aromatic silver-gray foliage. 9 to 12 inches. July to September.

LILIUM AURATUM. (Gold-banded Lily). Glistening ivorywhite, dotted with brownish spots and a gold band through the center of each petal. Fragrant. 2 to 3 feet. July and August. $40 \mathrm{c}$ each; $\$ 4.00$ per dozen.

LILIUM RUBRUM-MELPOMENE. Dull ivory-white thickly dotted with red spots, giving a rosy effect. 2 to 3 feet. July and August. $40 \mathrm{c}$ each; $\$ 4.00$ per dozen.

LILIUM TIGRINUM. ('Tiger Lily). Quite showy scarlet, with crimson dots. 4 to 5 feet. August.

LOBELIA CARDINALIS. (Cardinal Flower). Long spikes of intense red. 3 feet. July and August.

LOBELIA SYPHILITICA. (Great Lobelia). Spikes of deep royal purple; very attractive. 2 feet. September.

Prlces for perennials, unless otherwise noted, are 25 cents each; $\$ 2.50$ per dozen. Six of a variety at the dozen rate. Extra iarge clumos charged according to size. 
LUPINUS POLYPHILLUS. (Lupin). Deep blue flowers on long spikes, very handsome. 2 to 3 feet. June.

MONARDA ROSEA. (Bergamot). Fragrant rose-colored flowers. Spicy foliage. 2 to 3 feet. July and August.

OENOTHERA MISSOURIENSIS. (Evening Primrose). Large, deep, buttercup-yellow flowers spotted with red. 9 to 12 inches. June to September.

PAPAVER NUDICAULE. (Iceland Poppy). Beautiful blossoms the entire season of yellow, white, and orange. 12 inches.

PAPAVER ORIENTALE. (Oriental Poppy). Large, brilliant scarlet flowers, 4 to 6 inches in diameter. Very striking. 3 to 4 feet. May and June.

PENSTEMON BARBATUS TORREYI. (Beard Tongue.) Medium spikes of deep scarlet-red. 2 feet. June to August.

PENSTEMON DIGITALIS. Large spikes of white flowers, somewhat resembling foxglove. June and July. 2 to 3 feet.

PEONIES AND PHLOX, Our list of high-grade American and European varieties will be found listed in our special catalog, which we will gladly mail on application.

PHYSOSTEGIA VIRGINICA. (False Dragon Head). Tall erect spikes bearing pink flowers. Very pretty. 3 to 4 feet. July and August.

PLATYCODON GRANDIFLORA. (Chinese Balloon Flower). A bushy plant, bearing soft blue flowers all summer; buds resemble tiny balloons. 2 to 3 feet.

PLATYCODON ALBA. Same as the above, except that the flowers are clear white with purple veinings.

POLYMONIUM RICHARDSONI. (Jacob's Ladder). Finelycut foliage, bearing heads of bright blue flowers. 18 inches. June and July.

POLYMONIUM RICHARDSONI ALBA. A white variety of the above.

PYRETHRUM FLORA PLENA. (Feverfew). Very showy flowers of double pink, red, and white. 2 feet. June and July. $35 \mathrm{c}$ each; $\$ 3.50$ per dozen.

PYRETHRUM ULIGINOSUM. (Giant Ox-Eye Daisy). Numerous daisy-like blossoms. 4 to 5 feet high. September.

SCABIOSA CAUCASICA. (Mourning Bride). Delicate lilacblue flowers, borne in handsome bunches from June to September. 1 to $1 \frac{1 / 2}{2}$ feet.

SEDUM ACRE. (Stone Crop). Tiny flowers forming a carpet of golden yellow. Good for rock work. 4 to 6 inches. May and June.

SEDUM SPECTABILE. Rose and purple-colored flowers borne in large clusters. Very showy. 18 to 24 inches. June and July.

TROLLIUS EUROPAEUS. (Double Buttercup). Large, showy, lemon-yellow flowers. 15 to 18 inches. June and July.

VERONICA INCANA. (Speedwell). White woolly plants with pale blue flowers. 1 to $1 \frac{1}{2}$ feet high. Very ornamental for rockery or border. July and August.

VERONICA SUBSESSILIS. Medium to long spikes of deep blue flowers. 2 to 3 feet. July and August. $30 \mathrm{c}$ each; $\$ 3.00$ per dozen.

VIOLA CORNUTA. (Tufted Pansy). These ornamental plants bloom practically all summer; dwarf. 3 to 6 inches.

Admiration. Dark blue to soft purple, with dark splotches. Lutea Splendens. Deep, golden yellow.

Perfection. Light blue, very nice.

White Perfection. Fine white, sweet scented.

Prices for perennials, unless otherwise noted, are 25 cents each; $\$ 2.50$ per dozen. Six of a variety at the dozen rate. Extra large clumps charged according to size. 


\section{INDEX TO PEONIES}

\begin{tabular}{|c|c|}
\hline & \\
\hline ........ & \\
\hline delaide Delache ........ 7 & Enchanteresse $\ldots . .$. \\
\hline dmiral Togo ........... 13 & Estafette ........... \\
\hline dolphe Rousseau .......13 & Etta $\ldots \ldots \ldots \ldots \ldots$ \\
\hline lbert Crousse $\ldots \ldots \ldots \ldots 11$ & Eucharis $\ldots \ldots \ldots \ldots$ \\
\hline lexandre Dumas ........6. 6 . & Eugene Bigot...$\ldots$. \\
\hline Ifred de Musset $\ldots \ldots \ldots \ldots 9$ & Eugene Reignoux ..... \\
\hline lice de Julvecourt ...... 6 & Eugene Verdier ...... \\
\hline lsace Lorraine $\ldots \ldots \ldots \ldots 13$ & Eugenie Verdier ...... \\
\hline . P. Saunders .......... 19 & Evangeline $\ldots \ldots \ldots \ldots \ldots$ \\
\hline reos $\ldots \ldots \ldots \ldots \ldots \ldots \ldots \ldots, \quad 4$ & Exquisite $\quad \ldots \ldots \ldots \ldots \ldots$ \\
\hline rgus $\ldots \ldots \ldots \ldots \ldots \ldots \ldots$. 4 & Faribault $\ldots \ldots \ldots \ldots \ldots \ldots$, \\
\hline rmand Rousseau ........ 9 & Felix Crousse..$\ldots \ldots \ldots \ldots$ \\
\hline sa Gray ...............11 & Festiva Maxima ............ \\
\hline$\ldots \ldots \ldots \ldots 20$ & liczka ....... \\
\hline stin d'Hour .......... 7 & ence Nightingale ...... \\
\hline e $\ldots \ldots \ldots \ldots \ldots \ldots \ldots \ldots \ldots$ & heur $\ldots \ldots \ldots \ldots \ldots \ldots$.......... \\
\hline nche $\ldots \ldots \ldots \ldots \ldots \ldots 9$ & Frances Shaylor ......... 14 \\
\hline at-Garde $\ldots \ldots \ldots \ldots \ldots 5$ & Frances Willard .........20 \\
\hline eur Reymond ........13 & cois Rousseau ....... 14 \\
\hline less Schroeder ........11 & thee $\ldots \ldots \ldots \ldots \ldots \ldots{ }^{14}$ \\
\hline$\ldots \ldots \ldots \ldots 13$ & ral Custer \\
\hline amin Franklin ....... 20 & lor... . \\
\hline aire $\ldots \ldots \ldots \ldots \ldots \ldots$ & aine Bigot ........... 14 \\
\hline Mauve $\ldots \ldots \ldots \ldots \ldots 13$ & te $\ldots \ldots \ldots \ldots \ldots \ldots .14$ \\
\hline$\ldots \ldots \ldots 20$ & $\ldots \ldots \ldots \ldots \ldots 14$ \\
\hline de Neige $\ldots \ldots \ldots \ldots \ldots 9$ & e de $\mathrm{Cl}$ \\
\hline idissima $\ldots \ldots \ldots \ldots \ldots 6$ & nceaux .... 10 \\
\hline ne Allain $\ldots \ldots \ldots \ldots .9$ & raine $\ldots \ldots \ldots 14$ \\
\hline ste Brochet $\ldots \ldots \ldots \ldots$. 4 & st $\ldots \ldots \ldots \ldots$ \\
\hline les McKellip ........20 & e D. Bryan ........... \\
\hline y Hill $\ldots \ldots \ldots \ldots \ldots 19$ & diflora $\ldots \ldots \ldots \ldots \ldots$ \\
\hline$y \ldots \ldots \ldots 20$ & $\ldots \ldots \ldots \ldots 14$ \\
\hline Dubois $\ldots \ldots \ldots \ldots 11$ & eland...$\ldots \ldots 14$ \\
\hline tte $\ldots \ldots \ldots \ldots \ldots \ldots{ }^{4}$ & $n \ldots \ldots \ldots \ldots 14$ \\
\hline t $\ldots \ldots \ldots 13$ & isIey $\ldots \ldots \ldots 20$ \\
\hline de Diesbach $\ldots \ldots \ldots 6$ & ............... 10 \\
\hline in $\ldots \ldots \ldots \ldots \ldots \ldots 12$ & ay $\ldots \ldots \ldots \ldots$ \\
\hline$\ldots \ldots \ldots \ldots 13$ & ry $\ldots \ldots \ldots \ldots 20$ \\
\hline ne d'Or $\ldots \ldots \ldots \ldots .9$ & 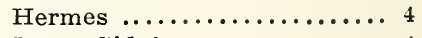 \\
\hline nce $\ldots \ldots \ldots \ldots \ldots \ldots 4$ & i Gidui $\ldots \ldots \ldots \ldots \ldots$. \\
\hline$\ldots \ldots \ldots \ldots \ldots \ldots \ldots, 8$ & es Boyd $\ldots \ldots \ldots \ldots$. \\
\hline issima $\ldots \ldots \ldots \ldots 6$ & y $\ldots \ldots \ldots \ldots 12$ \\
\hline ction $\ldots \ldots \ldots \ldots \ldots, 8$ & nn $\ldots \ldots \ldots$ \\
\hline ur Bretonneau ........6 6 & ichau ...... \\
\hline ur Caillot $\ldots \ldots \ldots \ldots 8$ & rc $\ldots \ldots \ldots$ \\
\hline r H. Barnsby ...... 13 & $\ldots \ldots \ldots \ldots \ldots$ \\
\hline ose $\ldots \ldots \ldots \ldots \ldots \ldots$ & lor $\ldots \ldots \ldots$ \\
\hline ster $\ldots \ldots \ldots \ldots \ldots .9$ & $\ldots \ldots \ldots \ldots$ \\
\hline$\ldots \ldots \ldots 4^{4}$ & dson ........ \\
\hline Wellington $\ldots \ldots \ldots .7$ & ge Berry $\ldots \ldots \ldots \ldots \ldots 20$ \\
\hline sse de Nemours ..... 8 & s Calot .............. \\
\hline Lyttleton $\ldots \ldots \ldots \ldots 9$ & lee. \\
\hline lard Andre $\ldots \ldots \ldots \ldots \quad 7$ & ld $\ldots \ldots \ldots \ldots 15$ \\
\hline lis Superba .........7 7 & way's Glorious $\ldots \ldots \ldots \ldots 15$ \\
\hline Edwin C. Shaw ......... 19 & Kelway's Qu \\
\hline beth Barrett Browning. 20 & nd $\ldots \ldots$. \\
\hline . Hill $\ldots \ldots \ldots \ldots \ldots$ & Lady Alexand \\
\hline E. J. Shaylor & Lady Lillian Ogle ...... \\
\hline lie Chevalier ...... & La Coquette ...... \\
\hline Ella Wheeler Wilcox .....20 & La Fayette ..............51 \\
\hline Elwood Pleas $\ldots \ldots \ldots \ldots \ldots 13$ & La Fee $\ldots \ldots \ldots \ldots \ldots \ldots . \ldots \ldots$ \\
\hline
\end{tabular}




\section{CHERRY HILL NURSERIES. \\ T. C. THURLOW'S SONS, INC.}

\section{Originators and Growers \\ Fine of Peonies}

West Newbury, Mass.

The American Peony Society has a membership wherever Peonies are grown in the United States and Canada, and the most noted Peony specialists in the world are enrolled. Its purpose is to cultivate a stronger and deeper love for that "Queen of Flowers," the Peony, and its work in verifying and describing the different varieties is most valuable.

It has published much valuable information in regard to this remarkable flower, and from time to time issues bulletins dealing with its culture, giving the members up to date information about new varieties and items of interest.

Don't you want to be a member of such an organization? The cost is not great, and you are entitled to all its past publications, and those issued through the year, as well as the Cornell Peony Bulletins accurately describing almost all the standard varieties. As members we extend to you a cordial invitation to join the Society, and are sure that you will gain much pleasure and profit therefrom.

A. H. Scott,

Date...$\ldots \ldots \ldots \ldots \ldots \ldots \ldots \ldots \ldots \ldots \ldots$

Treasurer, American Peony Society,

Front and Market Sts.,

Chester, $\mathrm{Pa}$.

1 hereby apply for membership in the American Peony Society and enclose $\left\{\begin{array}{l}\text { money order } \\ \text { check }\end{array}\right\}$ for Five Dollars, 'Two of which are for initiation fee, and the remaining Three for my first year's dues.

Please send all your bulletins as well as the Cornell Peony Bulletins, which, I understand, each member is entilled to free of charge.

Name.

Recommended by

Cherry Hill Nurseries,

T. C. Thurlow's Sons, Inc. 


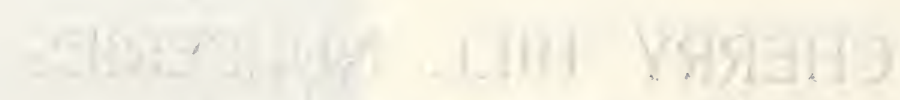

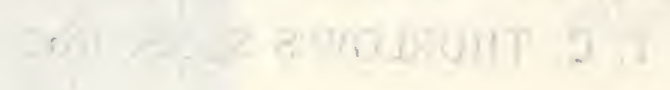

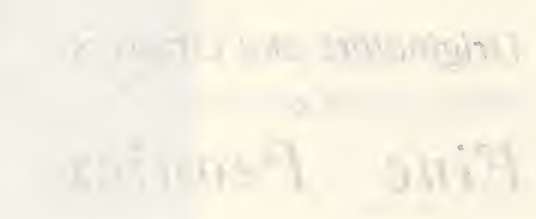


INDEX (continued)

Name

La Fiancee (double)........15

La Fiancee (single)........4

La France ...............15

La Lorraine ...............15

Lamartine .............10,15

La Perle ................15

La Rosiere ............. 12

La Tendresse ............. 12

La Tulipe ............... 8

Laura Dessert ............ 15

Le Cygne ...............16

Le Printemps ............. 5

L'Indispensable ...........10

Longfellow ............. 20

Lora Dexheimer ...........20

Louis Van Houtte .......... 6

Lord Kitchener .......... 16

Loveliness ............... 16

Madame Auguste Dessert... 16

Madame Barillet Deschamps 8

Madame Boulanger .........16

Madame Calot ..............10

Madame Camille Bancel.... 8

Madame Coste ........... 7

Madame Crousse .......... 10

Madame de Galhau ........ 8

Madame de Govin ......... 8

Madame de Verneville ...... 8

Madame D. Treyeran ...... 16

Madame Ducel ........... 8

Madame Emile Galle ...... 10

Madame Emile Lemoine .... 12

Madame Forel ............ 7

Madame Fould ........... 16

Madame Gaudichau ........ 16

Madame Geissler ......... 10

Madame Guyot ...........16

Madame Joanne Sallier.....16

Madame Jules Dessert ...... 16

Madame Loise Mere ....... 10

Madame Manchet ..........16

Madame Mechin ...........8 8

Madame Savreau ..........16

Mlle. Desbuissons .......... 10

Mlle. Jeanne Riviere .......16

Mile. Leonie Calot .......... 10

Mile. Marie Calot ...........10

Mlle. Rousseau .......... 12

Maifleuri ................. 5

Marcelle Dessert ............16

Marchioness of Landsdowne 12

Marechal Vaillant ........ 7

Marguerite Gaudichau ......16

Marguerite Gerard .........12 12

Marie ......................10

Marie Crousse .............16

Marie Jacquin ............... 10

Marie Lemoine ........... 10

Marquis C. Lagergren ...... 16

Martha Bulloch .............20

Mary Brand ............. 20

Mary Woodbury Shaylor .... 17

Midnight..$\ldots \ldots \ldots \ldots \ldots \ldots \ldots 20$

Mignon $\ldots \ldots \ldots \ldots \ldots \ldots \ldots \ldots \ldots \ldots \ldots \ldots \ldots \ldots$

Millais ................. 4

Milton Hill $\ldots \ldots \ldots \ldots \ldots \ldots, 17$

Mireille ................... 10

Mrs. Carew ................

Mrs. C. S. Minot ......... 17

Mrs. Key ............. 4

Mr. Manning ............ 10

Modele de Perfection ....... 8

Modeste Guerin .............10

Monsieur Dupont ..........11

Monsieur Jules Elie ........ 12

Monsieur Martin Cahuzac ... 17

Mont Blanc ...............17

M. Boucharlataine ......... 8

Neptune ................. 17

Noblissima...$\ldots \ldots \ldots \ldots \ldots \ldots 17$

Norfolk .................. 12

Nymphaea ............... 19

Octavie Demay ..............11
Name

Page

Odette ................. 17

Officinialis alba plena ....... 5

Officinialis rosea plena ......5

Officinalis rubra plena ..... 5

Officinalis sabina .......... 5

Old Silver Tip .............. 20

Paeonia Lutea ............. 5

Pasteur .................. 17

Perfection ................. 12

Perle Blanche ............... 5

Peter Barr ......... 5

Petite Renee ................ 12

Phillipe Rivoire ............. 17

Philomele ............... 7

Phoebe Carey ............... 20

Phyllis Kelway ........... 17

Pierre Dessert ............... 11

Pierre Duchartre ............17

Pierre Reignoux ........... 17

Pink Baroness Schroeder.....17

Pomponette

President Wilson ............19

Pride of Essex ............. 19

Primevere ................... 17

Prince Alexander .......... 4

Prince Bismarck ............ 4

Prince of Darkness .......21

Prince of Wales .......... 8

Princess Irene ............. 11

Princess of Wales .........4

Psyche ...................6 6

Purity ..................4

Queen Victoria ...........6 6

Raoul Dessert ............... 17

Reine Hortense ........... 17

Richard Carvel ...............

Rosa Bonheur ............ 18

Rosette ................ 18

Rosy Dawn ............. 4

R. P. Whitfield ......... 17

Rubra Superba ...........11

Ruth Brand ...............21

Samuel Henshaw ..........18

Sarah Bernhardt .......... 18

Secretary Fewkes ........... 18

Simonne Chevalier ........12

Single White ........... 4

Sinoutha ............... 5

Solange ................ 18

Souvenir du Dr. Bretonneau. 12

Souvenir de l'Exposition de

Bordeaux ................11

Souvenir de l'Exposition du

Mans ................. 8

Souvenir de l'Exposition

Universelle ............ 8

Souvenir de Louis Bigot....18

Stanley (double) .......... 18

Stanley (single) .......... 4

Suzette ..................... 18

Suzanne Dessert .............12

Tamatbako ............. 5

The Queen ................ 4

Therese ................... 18

Thomas C. Thurlow .........20

Torquemada .............. 7

Tourangelle ............. 18

Triomphe de $\mathrm{l}$ Exposition de

Lille .................11

Triomphe de Paris .........8 8

Umbellata Rosea .........8 8

Venus .................... 11

Victoire de la Marne ........18

Virginie ............... 11

Viscountess Folkestone .....9

Walter Faxon ............... 19

White Lady ............... 5

Whitleyi Major ............ 4

William F. Turner ........ 19

Winnifred Domme ...........21

Winnikenni ................ 20

Yeso .................... 5

Zoe Calot ................ 

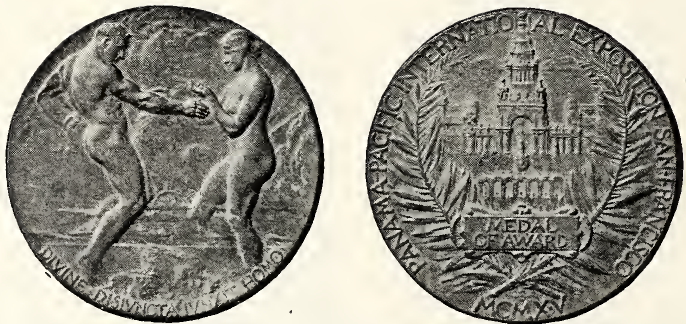

PANAMA-PACIFIC EXPOSITION MEDAL OF AWARD 